\author{
RESEARCH ARTICLE \\ 10.1029/2019JC015619 \\ Key Points: \\ - During downwelling season, \\ wave-current shear stress promotes \\ bottom nepheloid layers limited to \\ the inner shelf by a thermohaline \\ front \\ - During the upwelling season, \\ biogenic surface nepheloid layers \\ transport material offshore in the \\ Ekman layer \\ - Storm wave conditions combined \\ with hydrography are key factors \\ that explain the sediment \\ distribution on the Galician \\ continental shelf
}

Supporting Information:

- Supporting Information S1

Correspondence to:

N. Villacieros-Robineau,

nvrobineau@gmail.com

Citation:

Villacieros-Robineau, N., Zúñiga, D., Barreiro-González, B., Alonso-Pérez, F., de la Granda, F., Froján, M., et al. (2019). Bottom boundary layer and particle dynamics in an upwelling affected continental margin (NW Iberia). Journal of Geophysical Research: Oceans, 124. https://doi.org/ 10.1029/2019JC015619

Received 6 SEP 2019 Accepted 19 NOV 2019

Accepted article online 23 DEC 2019

(C)2019. American Geophysical Union. All Rights Reserved.

\section{Bottom Boundary Layer and Particle Dynamics in an Upwelling Affected Continental Margin (NW Iberia)}

\author{
Nicolás Villacieros-Robineau ${ }^{\mathbf{1}}$, Diana Zúñiga ${ }^{\mathbf{1}}$, Beatriz Barreiro-González ${ }^{\mathbf{1}}$, \\ Fernando Alonso-Pérez ${ }^{1}$, Francisco de la Granda ${ }^{2}$, María Froján ${ }^{1}$, Curtis A. Collins ${ }^{3}$, \\ Eric Desmond Barton ${ }^{1}$, and Carmen González Castro ${ }^{1}$ \\ ${ }^{1}$ Departamento de Oceanografía, Instituto de Investigacións Mariñas (IIM-CSIC), Vigo, Spain, ${ }^{2}$ Bundesamt für \\ Seeschifffahrt und Hydrographie, Hamburg, Germany, ${ }^{3}$ Department of Oceanography, Naval Postgraduate School, \\ Monterey, CA, USA
}

\begin{abstract}
The dynamics of the bottom boundary layer and their effects on the development of nepheloid layers (NLs) on a high-energy and upwelling-affected margin, the NW Iberian continental shelf, were studied by means of ADP currents, wave time series, and across-shelf hydrographic surveys covering an entire annual cycle. The bottom boundary layer hydrodynamics showed that high levels of bottom shear stress over the inner shelf occurred mainly during downwelling seasons, when there was a coupling between storm waves and intense currents. This wave-current coupling promotes strong resuspension events that favored the generation of bottom NLs (BNLs). BNLs were well developed on the inner continental shelf inshore of a thermohaline front generated by the interaction of the Iberian Poleward Current and the West Iberian Buoyant Plume. The existence of this front limited the extent of offshore export of resuspended particles during the downwelling season. In contrast, during the upwelling season, only thin BNLs were developed, and surface NLs, principally composed by biogenic particulate material, were advected offshore in the Ekman layer, often as part of the development of upwelling filaments. Our study confirmed that wave orbital velocity under stormy conditions, in combination with the hydrography, could explain the shoreward boundary of the Galician mud depocenter.
\end{abstract}

Plain Language Summary This manuscript mainly focuses on hydrodynamics of the bottom boundary layer and the effect of wave-current bottom shear stress on the development and modulation of nepheloid layers on the NW Iberia continental shelf during more than 1 year. During this period, we analyze the role of hydrographic seasonality of this coastal upwelling system in the behavior of nepheloid layers and the possible offshore export pathways of particulate matter to the adjacent ocean. In addition, wave climate over the continental shelf was analyzed together with this hydrographic context in order to explain the surface sediment distribution.

\section{Introduction}

Continental margins are among the most biogeochemically active areas of the biosphere, playing a key role in the cycling of organic matter (Falkowski et al., 1988; Liu et al., 2010; Walsh, 1991). In spite of covering $<10 \%$ of the total ocean surface, they account for over $20-50 \%$ of the total primary production and about $80 \%$ of the particulate organic carbon burial on continental margins (Hedges \& Keil, 1995; Wollast, 1998). One potential fate of the unburied organic material is the offshore export to the adjacent ocean (Liu et al., 2010; Muller-Karger et al., 2005; Wollast, 1998).

Several projects have provided evidence of lateral export of organic matter from different continental margins, in the Mid-Atlantic Bight (Biscaye et al., 1994; Falkowski et al., 1988), in the northern Bay of Biscay (Wollast \& Chou, 2001), on the European North Atlantic Margin (Mienert et al., 1998), off northern California (Nittrouer, 1999; Pilskaln et al., 1996), at the NW Iberian upwelling coast (Van Weering \& McCave, 2002), and in the Benguela upwelling system (Inthorn et al., 2006). The significance and conduit of lateral transport of organic carbon to the adjacent heterotrophic ocean (Del Giorgio et al., 1997) vary from margin to margin. Results from the Shelf Edge Exchange Processes experiment (SEEP) I and II programs (Biscaye et al., 1994; Falkowski et al., 1988) showed that 10\% (SEEP I) to 1\% (SEEP II) of the annual primary production occurring on the Mid-Atlantic Bight was exported (Biscaye et al., 1994). In contrast, Pilskaln et al. (1996) observed that $81 \%$ of the annual primary production can be exported in 
the coastal upwelling system of Monterey Bay (northern California). Surface nepheloid layers (SNLs), intermediate nepheloid layers (INLs), and bottom nepheloid layers (BNLs) constitute key conduit modes of offshore export of organic carbon (Bauer \& Druffel, 1998; Hwang et al., 2010). Lateral transport of particles in these layers is largely controlled by the hydrodynamics of the bottom boundary layer (BBL; Thomsen et al., 2002).

The NW Iberian coast constitutes the principal coastal upwelling system of Europe. Compared with other continental shelves, coastal upwelling regions are characterized by an enhancement of offshore export of organic matter to the adjacent ocean due to Ekman transport and mesoscale structures such as upwelling filaments and eddies (Arístegui et al., 2009; Pelegrí et al., 2005). Off the NW Iberian coast, the predominance of northeasterly winds from April-May to September-October is the main cause of upwelling (Fraga, 1981; Wooster et al., 1976), favoring the formation of upwelling filaments (Barton et al., 2001; Haynes et al., 1993) and consequently the surface shelf-ocean exchange. From September-October to April-May, the dominance of southerly winds favors the development of a northward Inshore Coastal Current (ICC) in the inner shelf and enhances the density-driven poleward current on the slope (Iberian Poleward Current [IPC]) that provides warm and salty water to the shelf (Frouin et al., 1990; Haynes \& Barton, 1990; Peliz, Dubert, Haidvogel, \& Le Cann, 2003, Peliz, Dubert, \& Haidvogel, 2003; Torres \& Barton, 2006, 2007). The IPC confines coastal waters over the shelf, precluding shelf-ocean exchange (Castro et al., 1997). Finally, the interaction of river runoff with the shelf hydrography generates the Western Iberian Buoyant Plume (WIBP; Peliz et al., 2002; Otero et al., 2008, 2009, 2010, 2013; Mendes et al., 2016).

Off the western Iberian coast, studies of seafloor dynamics and suspended sediment transport have been mainly focused on the large submarine canyons dissecting the Portuguese margin (Nazaré, LisbonSetubal, Cascais Canyons). The studies have been developed under the framework of the OMEX II (Van Weering \& McCave, 2002, and references therein), EUROSTRATAFORM (Weaver et al., 2006 and references therein), and HERMES (Masson \& Tyler, 2011; Weaver \& Gunn, 2009, and references therein) projects. North of $41^{\circ} \mathrm{N}$ on this coastal margin, observational efforts to analyze seafloor dynamics and suspended sediment transport on the continental shelf have been carried out only during the OMEX II project (1997-2000) (Huthnance et al., 2002; Oliveira et al., 2002; Vitorino et al., 2002; Van Weering et al., 2002) and recently during a short period in 2014 (Zhang et al., 2016). In the Douro river area, current and wave measurements during 6 months of winter and spring seasons showed the important role played by waves on the BBL dynamics and how its highly energetic levels during winter were the main factor in the formation of nepheloid layers (NLs) through seabed resuspension (Oliveira et al., 2002; Vitorino et al., 2002). Near the Porto Canyon, the offshore transport of suspended sediment has been evidenced by relatively intense bottom or intermediate detached NLs (Oliveira et al., 2002; Vitorino et al., 2002; McCave \& Hall, 2002). Conversely, on the Galician margin, there was no clear evidence of an offshore export to the adjacent ocean, and only weak NLs, probably generated by internal waves or upper slope currents, were advected northward alongshore with limited cross-slope transfer (Huthnance et al., 2002; Van Weering et al., 2002). Model-based studies pointed also to this idea indicating that sediment transport on the shelf would be controlled by tides, stratification, and wind-driven currents and increased by wind waves effects with weak or no offshore transport (Davies et al., 2002; Xing \& Davies, 2002). More recently, modeled wave storm conditions support the important role of waves on the bottom dynamics (Oberle, Storlazzi, et al., 2014) whose interaction with bottom currents was suggested by Zhang et al. (2016) to be the key factor to understand the storm-driven sediment transport. The presence of a thermohaline front and the possible winnowing effects of internal waves on unconsolidated sediments were also suggested to be important factors that can explain the mud depocenters shoreward and seaward limits, respectively (Zhang et al., 2016, 2019).

In this context, the aim of this manuscript is to understand for the first time the seasonal hydrodynamics of the BBL and their effects on the generation and modulation of NLs on the Galician continental shelf based upon the longest time series of ADP current measurements (more than 1 year), sediment trap monitoring, and monthly hydrographic surveys performed in this region. This study provides new insights into the role of these BBL and NLs on the offshore export of particulate matter and how it can be related to the distribution of seabed sediment along this highly energetic and upwelling affected margin. 


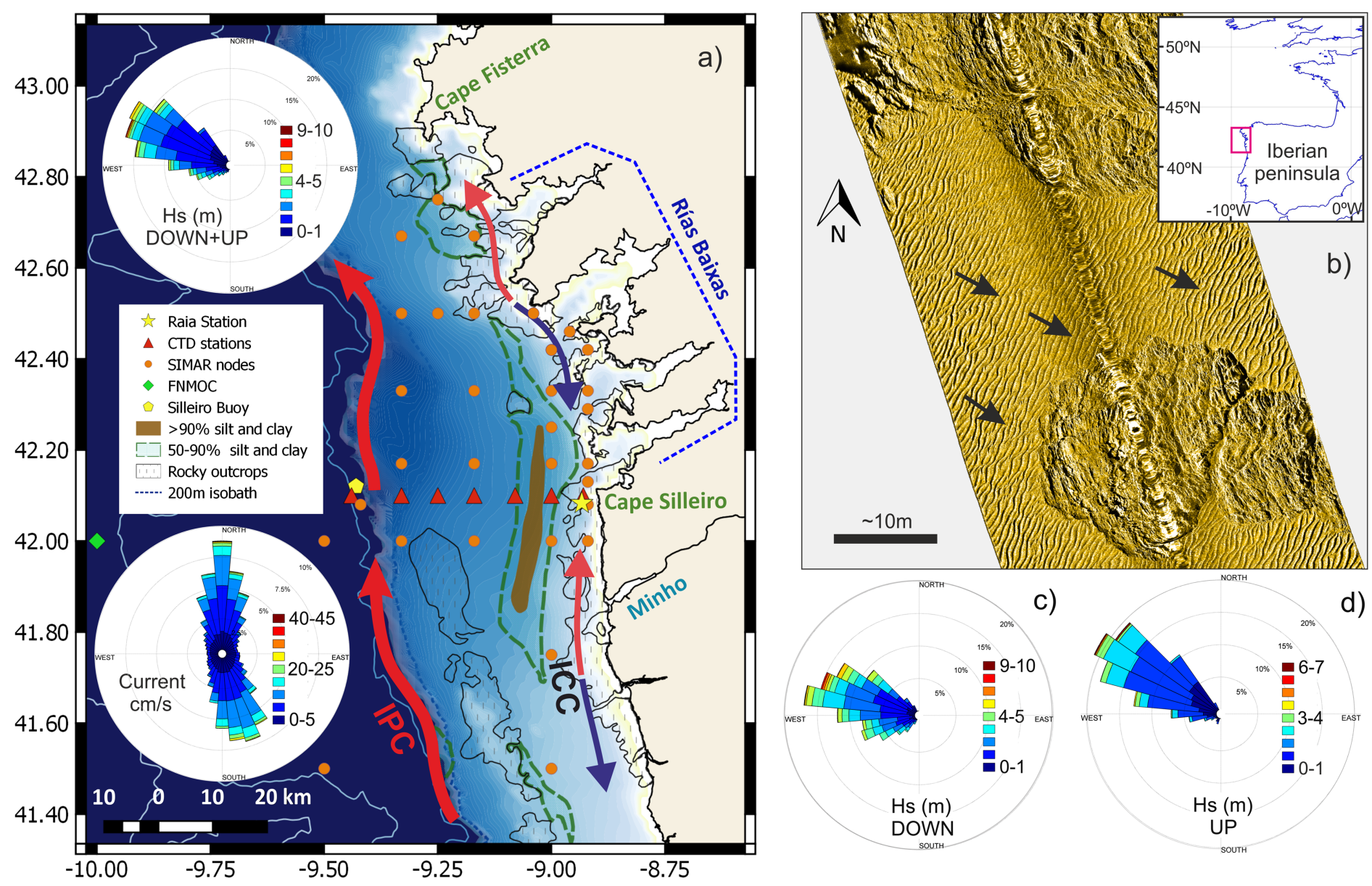

Figure 1. (a) Study area. RAIA station is represented by a yellow star; red triangles are the position of the seven CTD stations off Cape Silleiro. The upwelling index was determined for the FNMOC (see text for definition) grid shown by the green diamond. The yellow pentagon is the position of the Silleiro buoy. Orange points represent the location of SIMAR wave nodes. Light blue represents the bathymetry of the NW Iberian margin from coast to $200 \mathrm{~m}$ isobaths; dark blue area corresponds to $>200 \mathrm{~m}$ depth. Brown area is the Galician mud depocenter ( $>90 \%$ silt and clay, adapted from Lantzsch et al., 2009), and green dashed line represents the area with 50-90\% of silt and clay. Rocky outcrops are shown as shaded areas over the bathymetry (from Dias, González, et al., 2002). Red thick arrows over the slope represent the Iberian Poleward Current (IPC). Close to the coast, blue and orange arrows correspond to the Inshore Coastal Current (ICC) which flows southward during upwelling events (blue arrows) and northward during downwelling events (orange arrows). The wave rose for the study period is shown in the upper left and the current rose for the available time series at 3 mab measured at RAIA is shown in the lower left. Wave direction is the direction from which waves are coming, whereas for currents, it is the direction to where they flow. (b) Sonar image of the bottom surface near the RAIA station showing large-wave ripples whose crests are perpendicular to the dominant wave direction presented as black arrows. Irregular patches correspond to rocky outcrops. Superimposed, there is the index map of the Iberian Peninsula with a red square indicating the study area. (c) Wave rose during the downwelling seasons. (d) Wave rose for the upwelling seasons.

\section{Materials and Methods}

\subsection{Study Area}

The study area forms part of the NW Iberian continental margin centered on the Galician continental shelf offshore the four Rias Baixas (Figure 1a). Geomorphologically, this narrow and gently sloping continental shelf $(<40 \mathrm{~km})$ ends in a steep continental slope (López-Jamar et al., 1992). The coastline is characterized by the presence of four rias (Muros, Arousa, Pontevedra, and Vigo), and to the south, the Minho River defines the boundary with the northern Portuguese shelf. Rocky outcrops are present in the coastal zone and as separated zones on the outer shelf in the southern study area. Minho $\left(41.86^{\circ} \mathrm{N}, 8.87^{\circ} \mathrm{W}\right.$; Figure 1$)$ and Douro $\left(41.14^{\circ} \mathrm{N}, 8.68^{\circ} \mathrm{W}\right.$, not shown) rivers are the principal fresh water discharges and particulate matter sources for the NW Iberian margin. These rivers have been significantly modified by the construction of numerous dams that drastically diminish the particulate matter supply (Jouanneau et al., 2002). Sediment distribution is dominated by the Galician and Muros mud belts, mud patches, or depocenters situated between 100 and $120 \mathrm{~m}$ in the central part of the Rias Baixas area (Dias, González, et al., 2002, Dias, 
Jouanneau, et al., 2002; Lantzsch et al., 2009; Oberle, Storlazzi, et al., 2014, Oberle, Hanebuth, et al., 2014). A more detailed geomorphological description can be found in Van Weering et al. (2002).

The wave climate between 2003 and 2012 at Station RAIA was obtained from the analysis of modeled wave time series at the coastal Silleiro buoy position (wave rose in the upper left corner of Figure 1a). Waves were characterized by a significant wave height $(H s)$ of $1.5,>3.3$, and $>5.6 \mathrm{~m}$, which exceeded $50 \%\left(H s_{50 \%}\right.$, mean conditions), $10 \%$ ( $H s_{90 \%}$, energetic stormy conditions), and $1 \%$ ( $H s_{99 \%}$, extreme events) of the time, respectively. Northwesterly waves (NW, WNW, and W sectors) dominated $88 \%$ of the time, whereas southwesterly waves (SSW, SW, and WSW sectors) represented $<6.5 \%$. Highest values of $H s_{90 \%}$ were concentrated in the W and WNW sectors.

\subsection{Field Study}

From November 2008 to April 2010, an upward looking Sontek 500 ADP (configured for 3 m cell size and continuous 5 min sampling interval) was moored on the seabed in $75 \mathrm{~m}$ water depth at $42.083^{\circ} \mathrm{N}$ and $8.933^{\circ} \mathrm{W}$ (RAIA station, Figures 1 and S1 in the supporting information) near Cape Silleiro. An additional mooring line equipped with an automated Technicap PPS 4/3 sediment trap at $35 \mathrm{~m}$ water depth was deployed at RAIA station during the same period. In addition, during the study period, 15 hydrographic cruises were carried out along a $42.1^{\circ} \mathrm{N}$ across-shelf section. These cruises sampled monthly along seven equally spaced stations from the position of the coastal Silleiro buoy at $8.93^{\circ} \mathrm{W}$ ( $75 \mathrm{~m}$ depth) to a station located at $9.44^{\circ} \mathrm{W}$ ( $580 \mathrm{~m}$ depth; Figure 1). A CTD (Seabird 25) equipped with fluorescence, turbidity, and transmittance sensors was used for these hydrographic cruises. The cruises started at the shallow station between 08:00 and 11:00 and ended at the deepest station between 12:00 and 15:00. Surface sediment samples were recovered at the RAIA station with a Van Veen grab. Granulometric analysis was carried out on nonhomogenized subsamples of approximately $1 \mathrm{~g}$ after removing organic matter and carbonates from the bulk sample by adding $10 \% \mathrm{H}_{2} \mathrm{O}_{2}$ and $25 \% \mathrm{HCl}$, respectively. The analyses were performed with an LS100 Coulter Counter. Three main grain size categories were considered: sand ( $>63 \mu \mathrm{m})$, silt $(4-63 \mu \mathrm{m})$, and clay $(<4 \mu \mathrm{m})$. Samples near the ADP mooring showed values of $d_{50}$ around $50 \mu \mathrm{m}$ and $d_{90}=86.58 \mu \mathrm{m}$. The percentage of sand was $33.3 \%$ and $62.6 \%$ of silt and $4.1 \%$ of clay.

\subsection{Upwelling Index and Runoff}

Time series of offshore Ekman transport $\left(-Q_{x}, \mathrm{~m}^{3} \mathrm{~s}^{-1} \mathrm{~km}^{-1}\right)$, also called the Upwelling Index, UI, were downloaded online (http://www.indicedeafloramiento.ieo.es). This UI was computed every 6 hr according to Bakun (1973):

$$
U I=-Q_{x}=-\frac{\rho_{\mathrm{air}} C_{\mathrm{D}}|V| V_{y}}{\rho_{\mathrm{sw}} f},
$$

where $\rho_{\text {air }}$ is the density of air, $1.22 \mathrm{~kg} \mathrm{~m}^{-3}$ at $15{ }^{\circ} \mathrm{C} ; C_{\mathrm{D}}$ is a dimensionless empirical drag coefficient, $1.3 \times 10^{-3}$ according to Hidy (1972); $f$ is the Coriolis parameter $\left(9.76 \times 10^{-5}\right)$ at $42^{\circ} \mathrm{N} ; \rho_{\mathrm{sw}}$ is the density of seawater, $1,027 \mathrm{~kg} \mathrm{~m}^{-3}$; and $V$ land $V y$ are the modulus and southward component of the geostrophic winds centered at $42^{\circ} \mathrm{N}, 10^{\circ} \mathrm{W}$ (green diamond in Figure 1). Winds were estimated from surface atmospheric pressure fields (WXMAP atmospheric model) distributed by the U.S. Navy Fleet Numerical Meteorological and Oceanographic Center in Monterey, California (http://www.usno.navy.mil/FNMOC). Positive (negative) $U I$ values show the predominance of southward (northward) winds that induce upwelling (downwelling) on the shelf.

Estimates of Minho and Douro river discharges were based on gauge records available closest to the river mouth and take into account the basin area downstream from the gauge (https://github.com/PabloOtero/ uptodate_rivers/find/master, Otero et al., 2010).

\subsection{Wave Data and Bottom Wave Orbital Velocity}

Time series of significant wave height $(H s)$, peak wave period $\left(T_{p}\right)$, and direction of wave propagation at 31 locations on the continental shelf (Figure 1) were obtained from the SIMAR-44 database (Spanish acronym for Information System and Database for Ocean Waves) managed by Puertos del Estado (www.puertos.es) and used to characterize the wave climate. These 31 data nodes contain a 59-year hindcast of directional spectral wave and wind data every hour between 1958 and 2017. These nodes were interpolated to 369 
points inside the area delimited between $41.5-42.8^{\circ} \mathrm{N}$ and $8.75-9.5^{\circ} \mathrm{W}$ (Figure 1) in order to obtain greater grid resolution $\left(0.04^{\circ}\right.$ in longitude and $0.125^{\circ}$ in latitude, not shown) for computation of the wave bottom orbital velocity. The SIMAR-44 nodes closest to the coast (longitude $<9^{\circ} \mathrm{W}$ ) were not used in the interpolation to avoid problems of diffraction-refraction. At the RAIA station, wave climate was obtained from modeled wave time series (OLUCA mathematical model belonging to the University of Cantabria-IH Cantabria) at the position of the coastal Silleiro buoy $\left(42.10^{\circ} \mathrm{N}\right.$ and $8.93^{\circ} \mathrm{W}, 75 \mathrm{~m}$ depth, Code 7281 of Puertos del Estado, red triangle in Figure 1 closest to shore). Data gaps were filled using data from the SIMAR-44 Node 3014003 multiplying $H s$ by a factor of 1.1 .

Wave bottom orbital velocity $\left(U_{b}\right)$ was computed using the approximation for irregular waves proposed by Soulsby and Smallman (1986) and Soulsby (2006):

$$
\begin{aligned}
U_{b} & =\sqrt{2} U_{\mathrm{rms}}, \\
\frac{U_{\mathrm{rms}} T_{\mathrm{n}}}{H_{s}} & =\frac{0.25}{\left(1+A t^{2}\right)^{3}},
\end{aligned}
$$

where

$$
A=\left[6500+(0.56+15.54 \mathrm{t})^{6}\right]^{\frac{1}{6}},
$$

and

$$
t=\frac{T_{\mathrm{n}}}{T_{z}}=\frac{1}{T_{z}}\left(\frac{h}{g}\right)^{\frac{1}{2}},
$$

and

$$
T_{z}=0.781 T_{\mathrm{p}}
$$

$T_{\mathrm{p}}$ is the peak period, $T_{\mathrm{n}}$ is the natural scaling period, $U_{\mathrm{rms}}$ is the RMS bottom orbital velocity, $g$ the gravitational acceleration, and $h$ is the depth obtained from the updated 2009 version of the West-Iberian bathymetry (Quaresma \& Pichon, 2013), compiled by the Portuguese Instituto Hidrográfico and SHOM (French Service Hydrographique et Océanographique de la Marine).

\subsection{Total and Residual Currents}

ADP currents measured at RAIA station were used to compute the bottom current shear stress $\left(\tau_{\mathrm{c}}\right.$; see in Text S4) and to characterize the inner shelf current pulses during the study period. For the former, continuous 10 min averaged total currents were used taking into account tidal and residual currents. To compare the across-shelf (east-west) and alongshore (north-south) currents with winds (upwelling index), a residual, subtidal current was used. The residual currents were obtained by filtering hourly averaged ADP data with the $\mathrm{A}_{24}{ }^{2} \mathrm{~A}_{25}$ Godin (1972) filter. The resulting time series contained only frequencies less than one cycle per $30 \mathrm{hr}$. Current observation between 33 and $51 \mathrm{~m}$ above bottom (mab) were removed due to the noise that distorted the data.

\subsection{Bottom Shear Stress}

Estimates of mean and maximum combined bottom shear stress ( $\tau_{\mathrm{m}}$ and $\left.\tau_{\mathrm{max}}\right)$ estimates were made following the methodology proposed by Soulsby (1997) for combined waves and currents. It is summarized below in four steps as well as in a flow diagram in Figure S2.

1. First, skin-friction shear stress due to currents ( $\tau_{\mathrm{c}}$; see Text S4 and Figure S3 for details) and waves $\left(\tau_{\mathrm{w}}\right.$; see Text S3 and Figure S3 for details) were each calculated using the grain-related component of the roughness length $\left(Z_{0 s}=d_{50} / 12\right)$. The maximum skin-friction combined wave-current shear stress $\left(\tau_{\max }\right.$; see Text S5 and Figure S3 for details) was obtained for both and converted to maximum Shields parameters $\left(\theta_{\max }\right)$ as follows: 


$$
\theta_{\max }=\frac{\tau_{\max }}{g\left(\rho_{\mathrm{sw}}-\rho_{\mathrm{s}}\right) d_{50}}
$$

where $\rho_{\mathrm{s}}$ is sediment density $\left(2,650 \mathrm{~kg} \mathrm{~m}^{-3}\right)$ and $\mathrm{g}$ is gravitational acceleration $\left(9.81 \mathrm{~m} \mathrm{~s}^{-2}\right)$.

2. Next, the mobility conditions, $\theta_{\max }$, were compared with the critical threshold for motion initiation $\left(\theta_{\mathrm{cr}}\right)$ calculated for sediments characteristics at RAIA station using Soulsby and Whitehouse (1997) equation:

$$
\theta_{\mathrm{cr}}=\frac{0.3}{1+1.2 D_{*}}+0.055\left[1-\exp \left(-0.02 D_{*}\right)\right]
$$

where $D *$ is the dimensionless grain size given by

$$
D^{*}=\left[\frac{(g(s-1))}{v^{2}}\right]^{1 / 3} d_{50},
$$

and $S=\rho_{\mathrm{s}} / \rho_{\mathrm{sw}}$ and $\nu$ is the kinematic viscosity for seawater $1.182 \times 10^{-6} \mathrm{~m}^{2} \mathrm{~s}^{-1}\left(35\right.$ salinity and $\left.15^{\circ} \mathrm{C}\right)$. The value of $\theta_{\mathrm{cr}}$ is 0.1295 , and therefore, the critical shear stress $\left(\tau_{\mathrm{cr}}\right)$ is $0.1031 \mathrm{~Pa}$.

a If $\theta_{\max }<\theta_{\mathrm{cr}}$, the bed is immobile.

b If $\theta_{\text {cr }} \leq \theta_{\max } \leq 0.8$, the bed is mobile and rippled.

c If $\theta_{\max }>0.8$, the bed is mobile and flat with sheet flow.

3. For condition $\theta \mathrm{cr} \leq \theta \max \leq 0.8$, the height $(\Delta)$ and wavelength $(\lambda)$ of bedforms for currents and waves were calculated (see Text S6 for details) and only the largest height selected. Effective total roughness length $\left(Z_{0}\right)$ was obtained summing the skin friction (or grain-related, $Z_{0 \mathrm{~s}}$ ) and the form drag from bedforms $\left(Z_{0 f}\right)$ components.

$$
Z_{0}=Z_{0 \mathrm{~s}}+Z_{0 \mathrm{f}}
$$

4. Finally, total wave, current, and combined wave-current shear stress were recalculated using the total roughness length $\left(Z_{0}\right)$ as previously described in Step (1).

\subsection{Backscatter From ADP Echo Intensity and Total Mass Vertical Flux}

ADP signal strength decreases with range from the system due to geometric spreading. Absorption data from current profilers were corrected with the decay or signal strength loss (dB) computed following Sontek (1997):

$$
\text { Decay }=-20 \log _{10}\left(\frac{\text { Range }}{\cos (\varphi)}\right)-2 \alpha\left(\frac{\text { Range }}{\cos (\varphi)}\right)
$$

where Range is the vertical range from the system $(\mathrm{m}), \varphi$ is the transducer beam mounting angle $\left(25^{\circ}\right.$ for Sontek 500), and $\alpha$ is the absorption coefficient $\left(0.14 \mathrm{~dB} \mathrm{~m}^{-1}\right.$ for Sontek 500$)$. The conversion factor used to transform the signal amplitude in counts to $\mathrm{dB}$ is 0.43 .

Sediment trap sampling strategy and sample processing are explained in Zúñiga et al. (2016). Total mass flux was gravimetrically determined.

\section{Results}

\subsection{Meteorological and Hydrographic Conditions}

For the study period, downwelling and upwelling seasons were delimited based on the Upwelling Index (UI) and water column biogeochemical characteristics shown by Zúñiga et al. (2016) (Figure 2a). A comparison between mean long-term and mean monthly UI (respectively, green and red dotted lines in Figure 2a) shows a relatively more extended and intense downwelling season during 2009/2010. The 2009 upwelling season was variable, with more negative values for the mean monthly values than the long term means due to a higher frequency of relaxation or downwelling events during June and July 2009. 

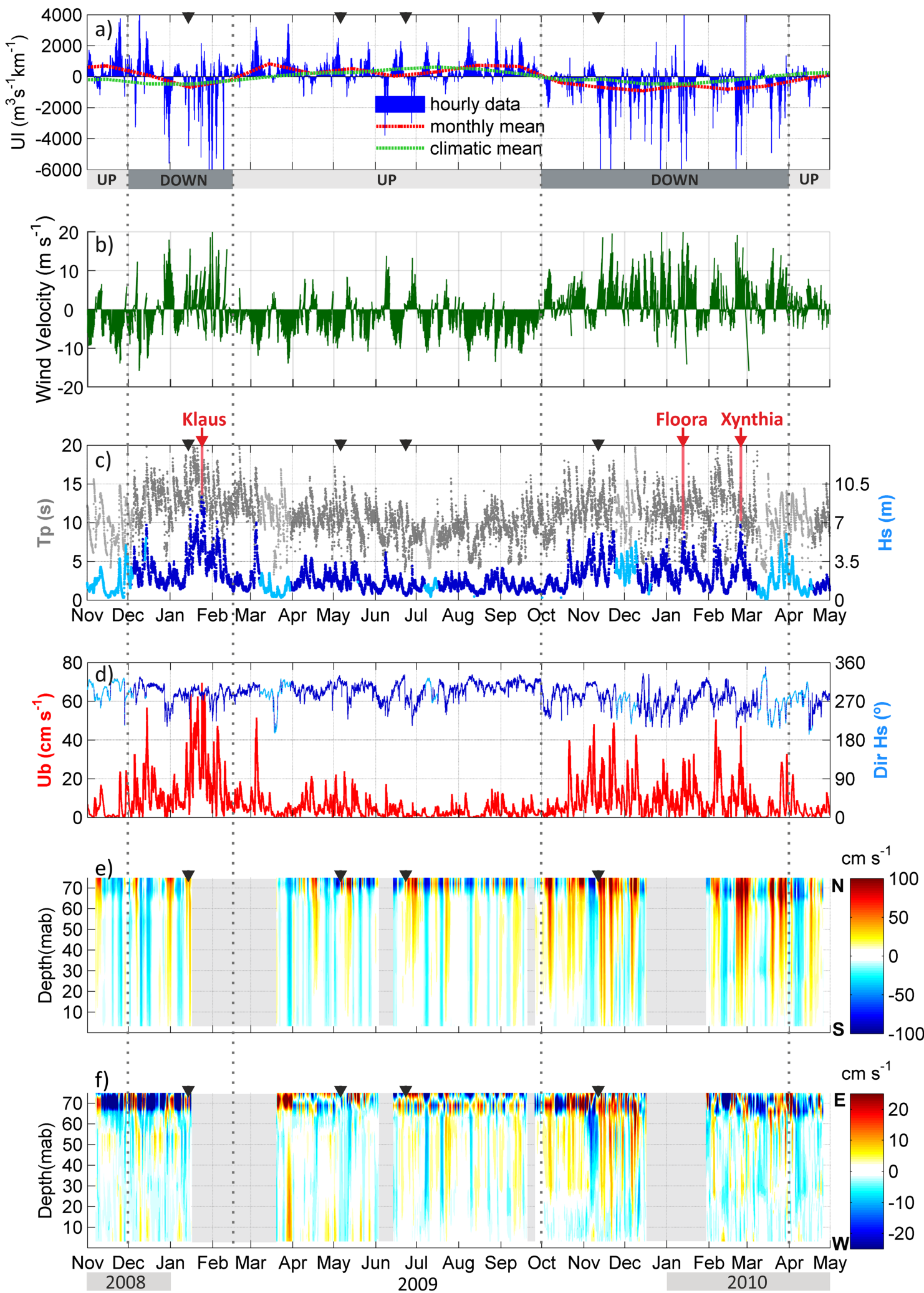

Figure 2. Meteorological and oceanographic conditions. Dotted lines differentiate downwelling (DOWN) and upwelling (UP) seasons. Black triangles represent the four hydrographic surveys presented in Figures 5-8. (a) Upwelling index time series: Blue and red lines are the 6 hr and monthly average values, respectively. Green line is the monthly climate average. (b) FNMOC wind velocity time series. (c) Significant wave height (Hs) and wave peak period ( $T_{\mathrm{p}}$ ) at RAIA station.

(d) Wave direction and wave orbital velocity at RAIA station. (e and f) North-south and east-west components of residual currents at RAIA station. 
During downwelling favorable seasons 2008/2009 (December 2008 to mid-February 2009) and 2009/2010 (October 2009 to March 2010), Minho and Douro river outflows were at their maximum levels, ranging from mean monthly values of 124 (August) to 600 (January) $\mathrm{m}^{3} \mathrm{~s}^{-1}$ and 114 (August) to 1,190 (January) $\mathrm{m}^{3} \mathrm{~s}^{-1}$, respectively (Figure 2b). The consecutive high runoff peaks during December $2009\left(2,800\right.$ and $\left.3,800 \mathrm{~m}^{3} \mathrm{~s}^{-1}\right)$, January $2010\left(3,500 \mathrm{~m}^{3} \mathrm{~s}^{-1}\right)$, and March $2010\left(5,000 \mathrm{~m}^{3} \mathrm{~s}^{-1}\right)$ represent the highest values for the study period. Such conditions were accompanied by strong storms, responsible for the highest significant wave height $(H s)$ for mean $\left(H s_{50 \%}=2.6 \mathrm{~m}\right)$ and extreme $\left(H s_{95 \%}=7.8 \mathrm{~m}\right)$ conditions (Figure $2 \mathrm{c}$ ). Wave storms mainly came from WNW to WSW sectors (Figure 2d), being more frequent during the downwelling season 2009/2010 when there was a train of storms from mid-October 2009 to early April 2010 (Hs up to 7 m; Figure 2c). The Extratropical Cyclones Klaus (23-24 January 2009), Floora (13-14 January 2010), and Xynthia (25-28 February 2010) (noted in Figure 2c), the first remarkable for surpassing the wind gusts records of the historic Cyclone Hortensia in 1984, had a clear impact on the development of wave storms (Hs maxima 9.3, 5.8, and $7 \mathrm{~m}$, respectively). In this hydrodynamic context, orbital velocity $\left(U_{b}\right)$ magnitude varied depending on the $T_{\mathrm{p}}$ trend (Figures $2 \mathrm{c}$ and $2 \mathrm{~d}$ ), with mean seasonal values of 15.7 and $9.8 \mathrm{~cm} \mathrm{~s}^{-1}$ for the downwelling season 2008/2009 and the downwelling season 2009/2010, respectively.

In contrast, during the upwelling favorable season 2009 (mid-February 2009 to September 2009), Minho and Douro river discharges were minimum, and waves significantly decreased to average values of $H s_{50 \%}=1.3 \mathrm{~m}$ and $H s_{95 \%}=3.9 \mathrm{~m}$ (Figures 2c and 3a). Lowest $H s$ values were registered between June and September 2009 when $H s$ mostly came from WNW-NW sectors, and monthly averaged UI dropped to minimum values (Figures 2a and 2c).

Residual currents at RAIA station were more intense in the alongshore (north-south) component (total current rose in the lower left of Figure 1). Alongshore residual velocity profiles (Figures 2e and 2f) had the same direction at all depths and were related to the prevailing wind regime, equatorward under upwellingfavorable conditions (northerly winds) and poleward in downwelling-favorable situations (southerly winds). The longest and strongest poleward current event of the study period occurred on 11 November 2009 when velocity magnitude achieved values as high as $40 \mathrm{~cm} \mathrm{~s}^{-1}$. On the other hand, the across-shelf (east-west) residual component was weaker than $20 \mathrm{~cm} \mathrm{~s}^{-1}$ for the entire sampling period (Figure $2 \mathrm{f}$ ). It showed significant two-layer behavior, principally under upwelling conditions when an eastward or shoreward component $\left(<5 \mathrm{~cm} \mathrm{~s}^{-1}\right)$ was observed between the bottom and 10 to $30 \mathrm{mab}$ and a westward or offshore component (up to $-25 \mathrm{~cm} \mathrm{~s}^{-1}$ ) in the upper layers (Figure 2f). This difference between bottom and upper layers was less defined during downwelling phases when values $<7 \mathrm{~cm} \mathrm{~s}^{-1}$ were observed for bottom offshore currents and up to $25 \mathrm{~cm} \mathrm{~s}^{-1}$ for the shoreward-flowing upper layers. Residual bottom currents at 3 mab oscillated around mean seasonal values of 7.9 (maximum 40) $\mathrm{cm} \mathrm{s}^{-1}$ and 7.6 (maximum 32) $\mathrm{cm} \mathrm{s}^{-1}$ for downwelling and upwelling seasons, respectively (Figure 2e).

\subsection{Temporal Variability of Bottom Shear Stress, Backscatter, and Total Mass Fluxes}

Total current, wave, and combined wave-current shear stresses are presented and analyzed to show the temporal variability and relative magnitude of bottom stress due to these various processes.

\subsubsection{Wave Shear Stress}

Wave shear stress responded to orbital velocity $\left(U_{b}\right)$ variability, principally during downwelling seasons (Figures 3 and 4 and Table 1). Maximum values were observed under stormy conditions with values ranging from 1.5 Pa up to 4.5 Pa, the latter during Extratropical Cyclone Klaus (Figure 3b). In seasonal terms, wave shear stress was clearly a factor of 3-4 times greater during the downwelling season $\left(\tau_{\mathrm{w} 95 \%}=1.89 \mathrm{~Pa}\right.$ vs. 0.54 Pa for downwelling and upwelling seasons, respectively) (Figures $4 \mathrm{a}$ and $4 \mathrm{~b}$ and Table 1).

\subsubsection{Current Shear Stress}

Current shear stress, from total currents, depended on the development of the logarithmic profile occurring as the upwelling index increased or during high tides, as has been observed in the Ría de Vigo (VillacierosRobineau et al., 2013). For periods with current measurements, the estimated current shear stress was lower than wave shear, except during certain short events, for example, those occurring in March 2009 (0.56 Pa), October 2009 (maximum 1.62 Pa), mid-November 2009 (maximum 1.72 Pa), the end of February 2010 (1.32 $\mathrm{Pa}$ ), the end of March 2010 (maximum $1.48 \mathrm{~Pa}$ ), or even during summer 2009 (blue triangular ticks in Figure $3 \mathrm{~b}$ ) when wave shear remained near its minimum levels. Seasonally, both total current shear and total current speed at 3 mab (see Figure S4 for details) were greater during downwelling than upwelling 


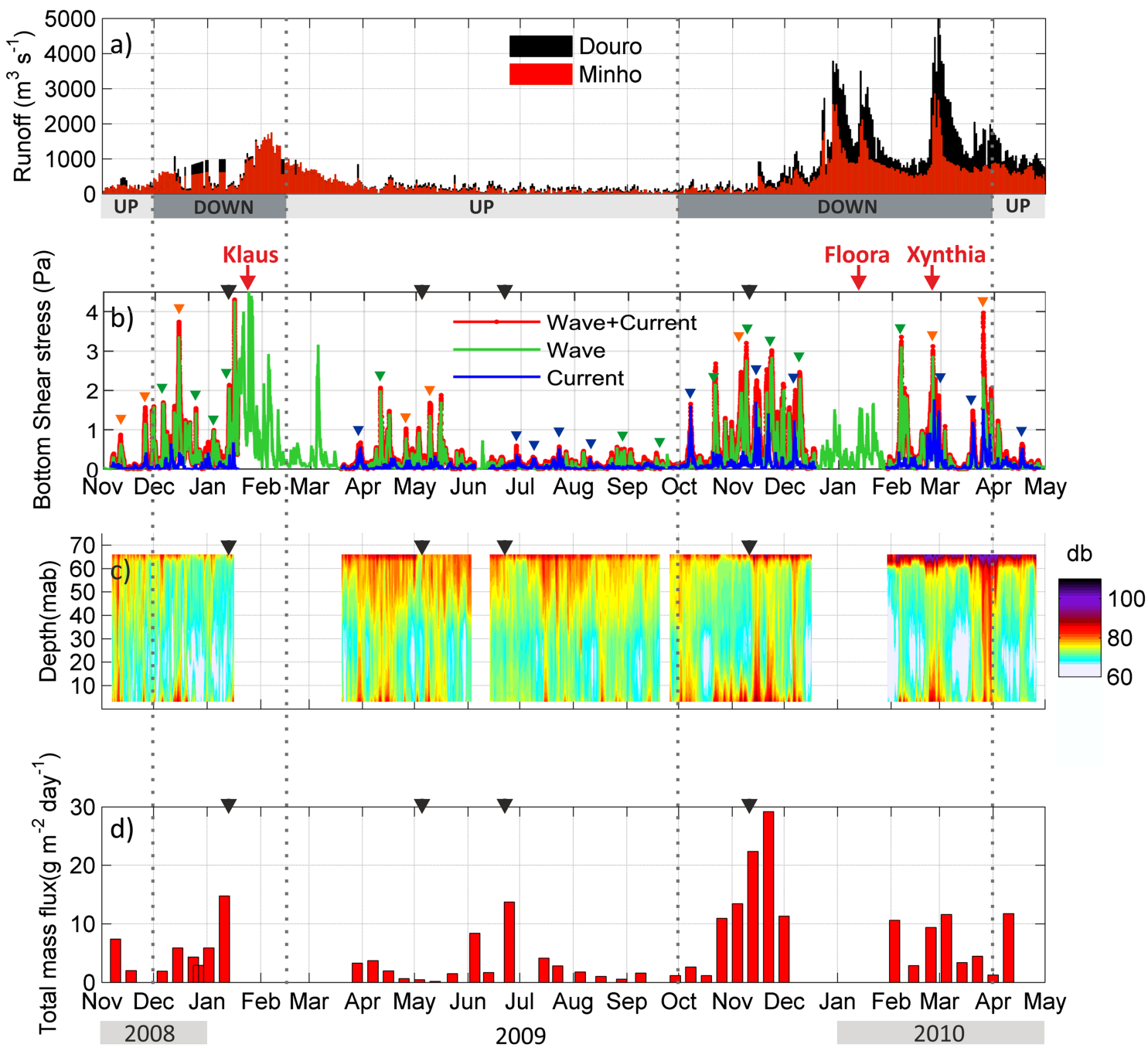

Figure 3. Total shear stress, backscatter, and total mass flux. Dotted lines differentiate downwelling (DOWN) and upwelling (UP) seasons. Black triangles represent the four hydrographic surveys. (a) Douro and Minho river discharges. (b) Wave (green), current (blue), and combined wave-current (red) bottom shear stress at RAIA station. Green, blue, and red triangular ticks depict the shear events dominated by waves, currents, or codominated by both waves and currents, respectively. (c) Corrected backscatter signal at RAIA station. (d) Total mass flux from the sediment trap moored at RAIA station.

season $\left(\tau_{\mathrm{c} 95 \%}=0.52 \mathrm{~Pa}\right.$ vs. $0.19 \mathrm{~Pa}$ for downwelling and upwelling seasons, respectively) (Figures $4 \mathrm{e}$ and $4 \mathrm{f}$ and Table 1).

\subsubsection{Combined Wave-Current Shear}

Total combined wave-current shear stress did not show a clear dominance of waves or currents. There were events when currents significantly increased the total combined shear, as occurred in November and December 2008, spring 2009, and the first two peaks of November 2009 (red triangular ticks in Figure 3b). The seasonal trend of the total combined wave and current shear also showed more energetic conditions during the downwelling seasons $\left(\tau_{\max 95 \%}=1.89 \mathrm{~Pa}\right.$ vs. $0.64 \mathrm{~Pa}$ for downwelling and upwelling seasons, respectively; Figure 4g and Table 1).

Total wave-current shear peak values were highly associated with the peaks of the deepest backscatter signal level ( $3 \mathrm{mab}$ ). This relationship was independent of the main forcing factor of the shear stress: currents (e.g., end of March, October, mid-November of 2009, or March 2010), waves (end of January 2009, late October 2009, November-December 2009, and February 2010), or the combined wave current (NovemberDecember 2008, November 2009, and end of March 2010) (Figures 3b and 3c). There was a significant correlation between total shear stress and backscatter for the 3 mab time series $(r=0.56)$. On the other hand, during the downwelling season 2009/2010 and upwelling season 2010, backscatter signals in the upper 

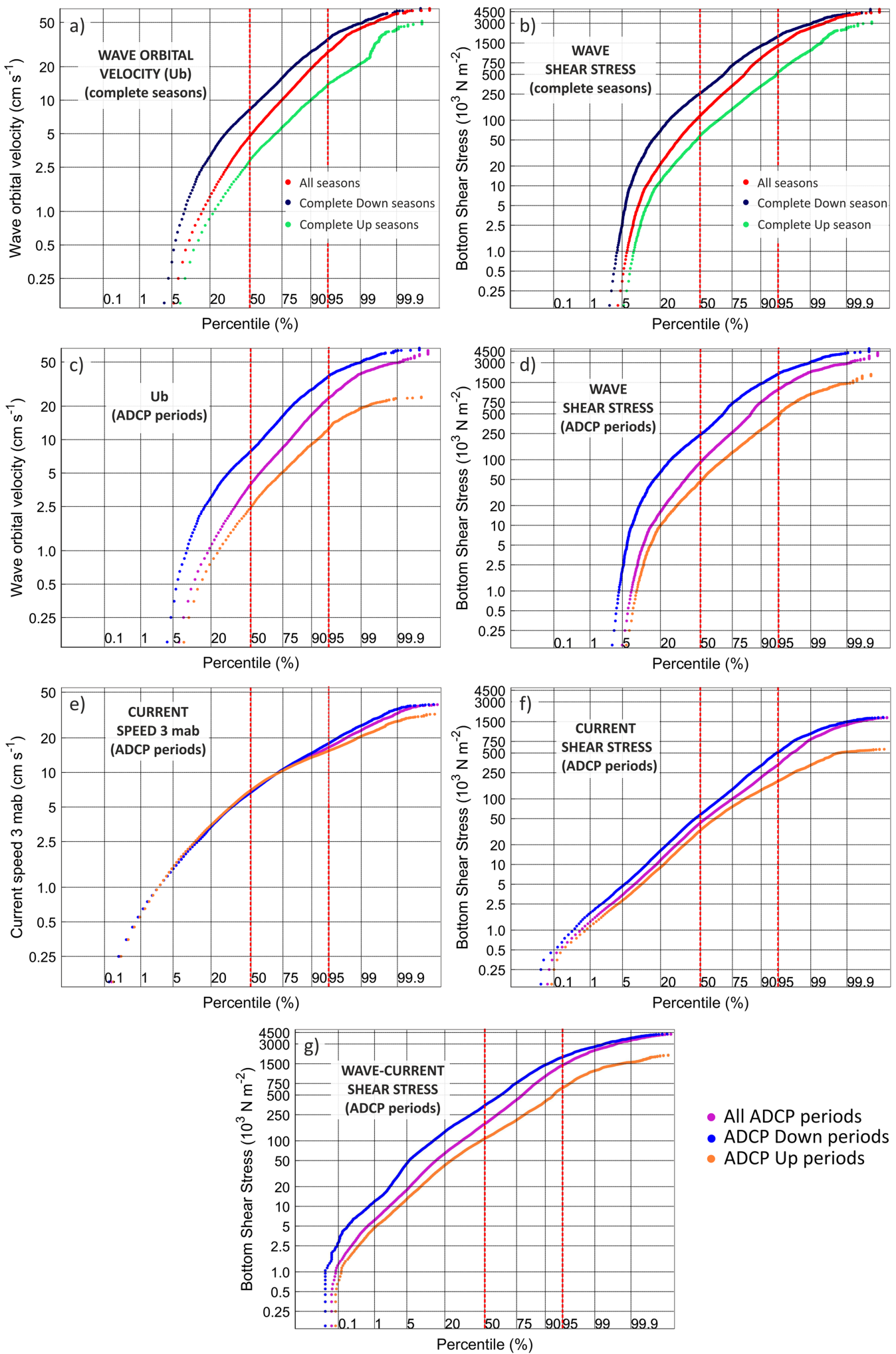

- All ADCP periods

- ADCP Down periods

- ADCP Up periods

Figure 4. Cumulative probability distributions of wave and current velocity and stresses for all periods (red or magenta), downwelling (dark blue and blue), and upwelling (green or orange) periods. (a) Wave orbital velocity for all periods, $U_{b}\left(\mathrm{~cm} \mathrm{~s}^{-1}\right.$ ). (b) Total wave shear stress (10 Pa) for all periods with ADP data, (c) wave orbital velocity, $U_{b}\left(\mathrm{~cm} \mathrm{~s}^{-1}\right)$, for all periods with ADP data, and (d) total wave shear stress $\left(10^{3} \mathrm{~Pa}\right)$ for all periods with ADP data, (e) 10 min averaged total current speed at $3 \mathrm{mab}\left(\mathrm{cm} \mathrm{s}^{-1}\right)$ for all periods with ADP data, (f) total current shear stress $\left(10^{3} \mathrm{~Pa}\right)$, and $(\mathrm{g})$ total combined wave-current shear stress $\left(10^{3} \mathrm{~Pa}\right)$ for all periods with ADP data. 
Table 1

Mean Regime Values (50th and 95th Percentiles) of the Wave Orbital Velocity $\left(U_{b}\right)$, the 10 min Averaged Current Speed 3 mab, and the Bottom Shear Stress

\begin{tabular}{|c|c|c|c|c|c|c|c|c|c|c|}
\hline \multirow[b]{3}{*}{ Percentile (\%) } & \multicolumn{2}{|c|}{$U_{b}\left(\mathrm{~cm} \mathrm{~s}^{-1}\right)$} & \multicolumn{2}{|c|}{ Current $\left(\mathrm{cm} \mathrm{s}^{-1}\right) 3 \mathrm{mab}$} & \multicolumn{6}{|c|}{ Shear stress $(\mathrm{Pa})$} \\
\hline & \multirow[b]{2}{*}{50} & \multirow[b]{2}{*}{95} & \multirow[b]{2}{*}{50} & \multirow[b]{2}{*}{95} & \multicolumn{2}{|c|}{ Wave only } & \multicolumn{2}{|c|}{ Current only } & \multicolumn{2}{|c|}{ Wave-current } \\
\hline & & & & & 50 & 95 & 50 & 95 & 50 & 95 \\
\hline All seasons & 4.8 & 27.1 & & & 0.12 & 1.37 & & & & \\
\hline Complete DW season & 8.2 & 35.2 & & & 0.26 & 1.89 & & & & \\
\hline Complete UP season & 2.9 & 13.8 & & & 0.06 & 0.54 & & & & \\
\hline All ADCP periods & 4.0 & 23.6 & 6.9 & 16.6 & 0.09 & 1.18 & 0.04 & 0.33 & 0.18 & 1.43 \\
\hline ADCP DW periods & 7.9 & 37.3 & 6.7 & 18.0 & 0.24 & 2.03 & 0.06 & 0.52 & 0.34 & 1.89 \\
\hline ADCP UP periods & 2.4 & 12.5 & 7.0 & 15.4 & 0.05 & 0.45 & 0.03 & 0.19 & 0.11 & 0.64 \\
\hline
\end{tabular}

Note. DW and UP are downwelling and upwelling seasons, respectively.

layers increased with an intensification of Minho and Douro runoff (Figure 3c). During the upwelling season 2009 and beginning of October 2009, high levels of backscatter ( 75 to $85 \mathrm{~dB}$ ) from the sea surface down to 40 mab resulted mainly from biological production (as shown in Zúñiga et al., 2016) as runoff was negligible.

Magnitude of total mass particulate fluxes (TMF) ranged around mean seasonal values of 8,800 \pm 7,787 and $3,540 \pm 3,815 \mathrm{mg} \mathrm{m}^{-2}$ day $^{-1}$ for downwelling and upwelling seasons, respectively. It showed an overall correlation with total combined wave-current shear stress and backscatter, especially during NovemberDecember 2009 and February-March 2010 when the gradual increase in TMF ran parallel to total shear stress increments (Figures 3b-3d). Peaks of TMF of late June 2009 and early April 2010 were not associated with increase of total shear stress but rather with increased surface backscatter signal suggesting that these TMF peaks resulted from biological production in the surface water and high river runoff respectively (Zúñiga et al., 2016, 2019).

\subsection{Development of NLs Under Different Oceanographic Conditions}

Among the 15 cruises covering the study period, four oceanographic scenarios were selected as representative examples for the different development stages of NLs in the NW Iberian coastal upwelling region. A black triangle in Figures 2 and 3 indicates the start of each of the chosen cruises.

\subsubsection{Winter Mixing and Strong River Discharge: 13 January 2009}

The section of 13 January 2009 was preceded by the passage of a low-pressure system that conditioned the observed wind, wave, and rainfall regimes (Figures 2 and 3). During this cruise, downwelling-favorable southerly winds enhanced poleward current velocities of $12 \mathrm{~cm} \mathrm{~s}^{-1}$ and westerly wave storms reaching $H s$ of $5 \mathrm{~m}$. Intense runoff from the Douro and Minho rivers, up to $1,000 \mathrm{~m}^{3} \mathrm{~s}^{-1}$, had a significant effect on the water column thermohaline structure favoring the development of the WIBP. Temperature and salinity distributions marked a well-defined thermohaline front between river and more saline ocean waters, conveyed northward by the IPC (Figures $5 \mathrm{a}$ and $5 \mathrm{~b}$ ). This front was situated between Stations 3 and 4 (18 to $22 \mathrm{~km}$ from the coastline) with a salinity difference of 0.5 . Fluorescence contours did not show significant differences, but vertical distributions of transmittance and turbidity indicated the presence of a BNL (60\% to $90 \%$ and $>2$ FTU, respectively) which extended from the coast toward the thermohaline front (Figures 5e and 5f). The development of the BNL was enhanced by storm waves (total combined wavecurrent shear stress reached $2.14 \mathrm{~Pa}$ ). A less intense SNL ( $<2$ FTU) measured at the inner station was associated with a low density layer corresponding to the WIBP (Figure 5c).

\subsubsection{Spring Regime of Upwelling and Offshore Ekman Transport: 5 May 2009}

The first days of May 2009 were characterized by the presence of high pressure conditions, leading to a prevalence of upwelling favorable northerly winds (between 5 and $12.5 \mathrm{~m} \mathrm{~s}^{-1}$ ) during the section of 5 May 2009 (Figures 2 and 3). River contribution was relatively low $\left(<200 \mathrm{~m}^{3} \mathrm{~s}^{-1}\right)$ compared with the previous winter section, and the wave regime was characterized by low energy conditions ( $H s 1$ to $1.5 \mathrm{~m}$, total combined wave-current shear stress levels $<0.2 \mathrm{~Pa}$ ) even though there was a brief NW storm 3 days before the cruise $(H s<3 \mathrm{~m})$.

Water column thermohaline properties showed the uplift of isotherms, isohalines, and isopycnals toward the coast (Figures 6a-6c) due to upwelling of cold and saline subsurface waters. This thermohaline 

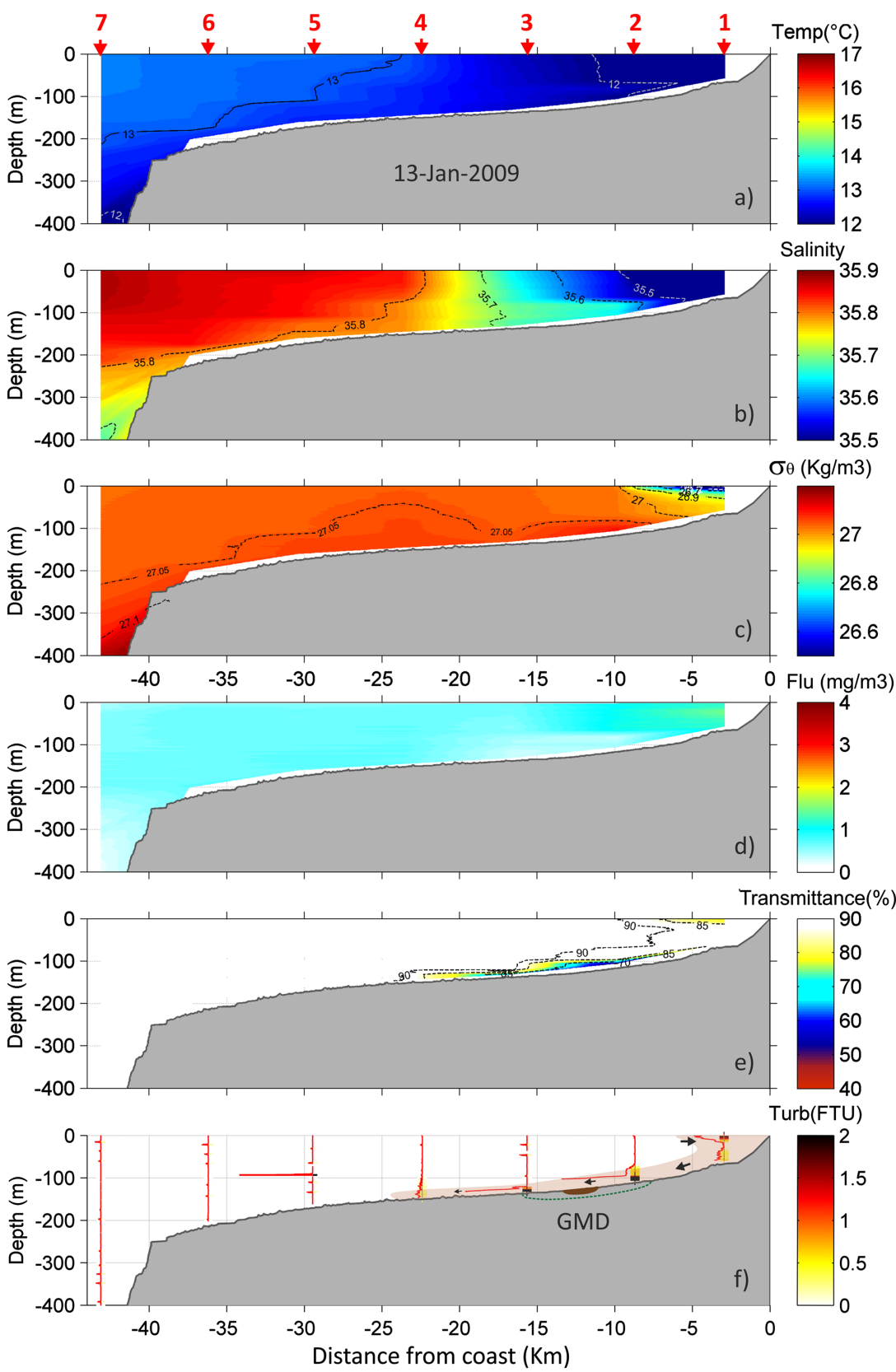

Figure 5. Hydrographic section along $\left(42.1^{\circ} \mathrm{N}\right)$ during the 13 January 2009. Position of the CTD stations are indicated along the upper abscissa of (a). (a) In situ temperature $\left({ }^{\circ} \mathrm{C}\right.$ ). (b) Practical salinity. (c) Potential density anomaly $\left(\mathrm{kg} \mathrm{m}^{-3}\right)$. (d) Fluorescence $\left(\mathrm{mg} \mathrm{m}^{-3}\right)$. (e) Transmittance (\%). (f) Turbidity (FTU). In (f), both the vertical profile of FTU and the magnitude (a color gradient) are shown, the Galician mud depocenter (GMD) is shown in brown, and black arrows represent the assumed across-shelf residual circulation.

structure was consistent with the current circulation pattern, characterized by an intensification of the alongshore residual current component $\left(<25 \mathrm{~cm} \mathrm{~s}^{-1}\right)$ moving equatorward and an across-shelf component advected oceanward at the sea surface and coastward at the bottom (Figures 2e and 2f). There was a subsurface fluorescence maximum at the pycnocline depth, indicating relatively high chlorophyll-levels, and the development of a biological SNL (subsurface turbidity about 0.5 FTU and transmittance less than $85 \%$ along the entire section; Figures 6c-6f). This SNL was consistent with an incipient filament observed in MODIS chlorophyll-a satellite imagery during 4 and 7 May (not shown). An incipient BNL with low turbidity values ( $<0.8 \mathrm{FTU}$ ) was observed at the inner shelf (Figure $6 \mathrm{f}$ ). 

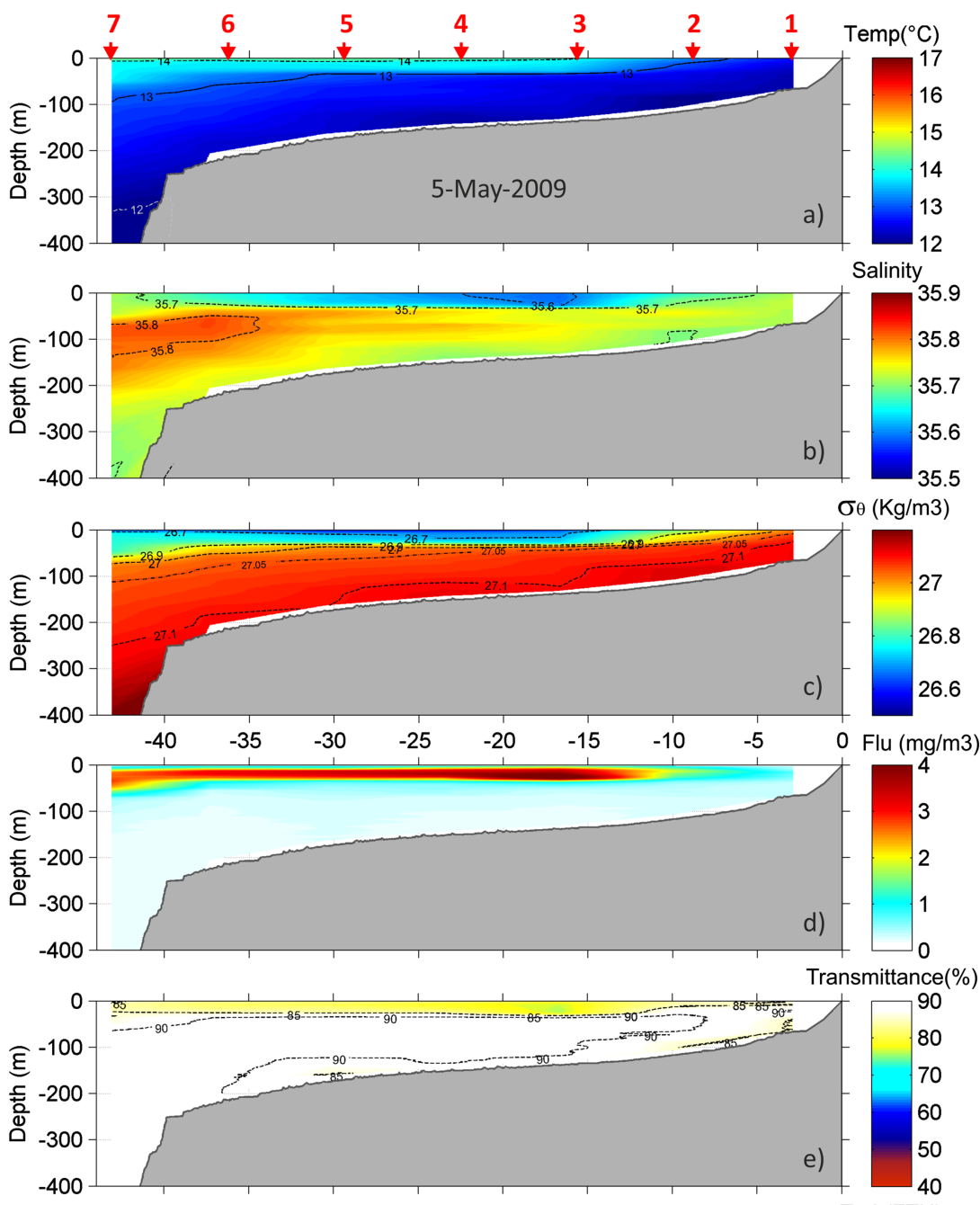

Turb(FTU)

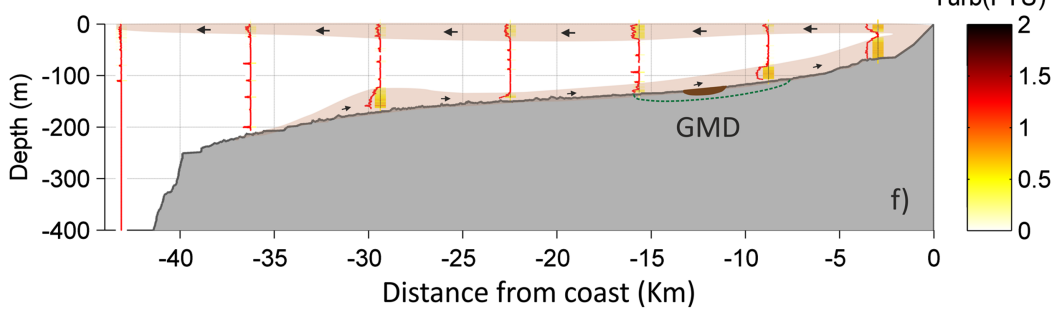

Figure 6. Hydrographic section along $42.1^{\circ} \mathrm{N}$ during the 5 May 2009. Panels are explained in Figure 5.

\subsubsection{Summer Regime of Relaxation and High Stratification Conditions: 22 June 2009}

The section of 22 June 2009 (Figures 2 and 3) took place during the spin down of a strong upwelling event (UI peak $>2,000 \mathrm{~m}^{3} \mathrm{~s}^{-1} \mathrm{~km}^{-1}$ ). Northerly winds reached $12.6 \mathrm{~m} \mathrm{~s}^{-1}$ during the days before the cruise and dropped to $2-5 \mathrm{~m} \mathrm{~s}^{-1}$ during the sampling. Surface currents reflected the transition from upwelling conditions, with equatorward $\left(<25 \mathrm{~cm} \mathrm{~s}^{-1}\right)$ and seaward $\left(18 \mathrm{~cm} \mathrm{~s}^{-1}\right)$ currents during the previous week, to downwelling conditions with poleward $\left(25 \mathrm{~cm} \mathrm{~s}^{-1}\right)$ and shoreward $\left(15 \mathrm{~cm} \mathrm{~s}^{-1}\right)$ currents in the following week. Bottom currents were always less than $5 \mathrm{~cm} \mathrm{~s}^{-1}$ for the days before and after the sampling. No significant levels of runoff were registered, and the wave regime changed from NW swell of 0.7-2.4 m to minimum values of $H s$ around $0.6 \mathrm{~m}$ during the day of the section (Figures $2 \mathrm{~b}$ and $2 \mathrm{c}$ ). Total combined wave-current shear stress did not exceed $0.12 \mathrm{~Pa}$ (Figure 3b). Water column structure was marked by an intense stratification in the upper layers ( $<30 \mathrm{~m}$ depth; Figures $7 \mathrm{a}-7 \mathrm{c}$ ) as observed in the temperature (differences from 14 to 

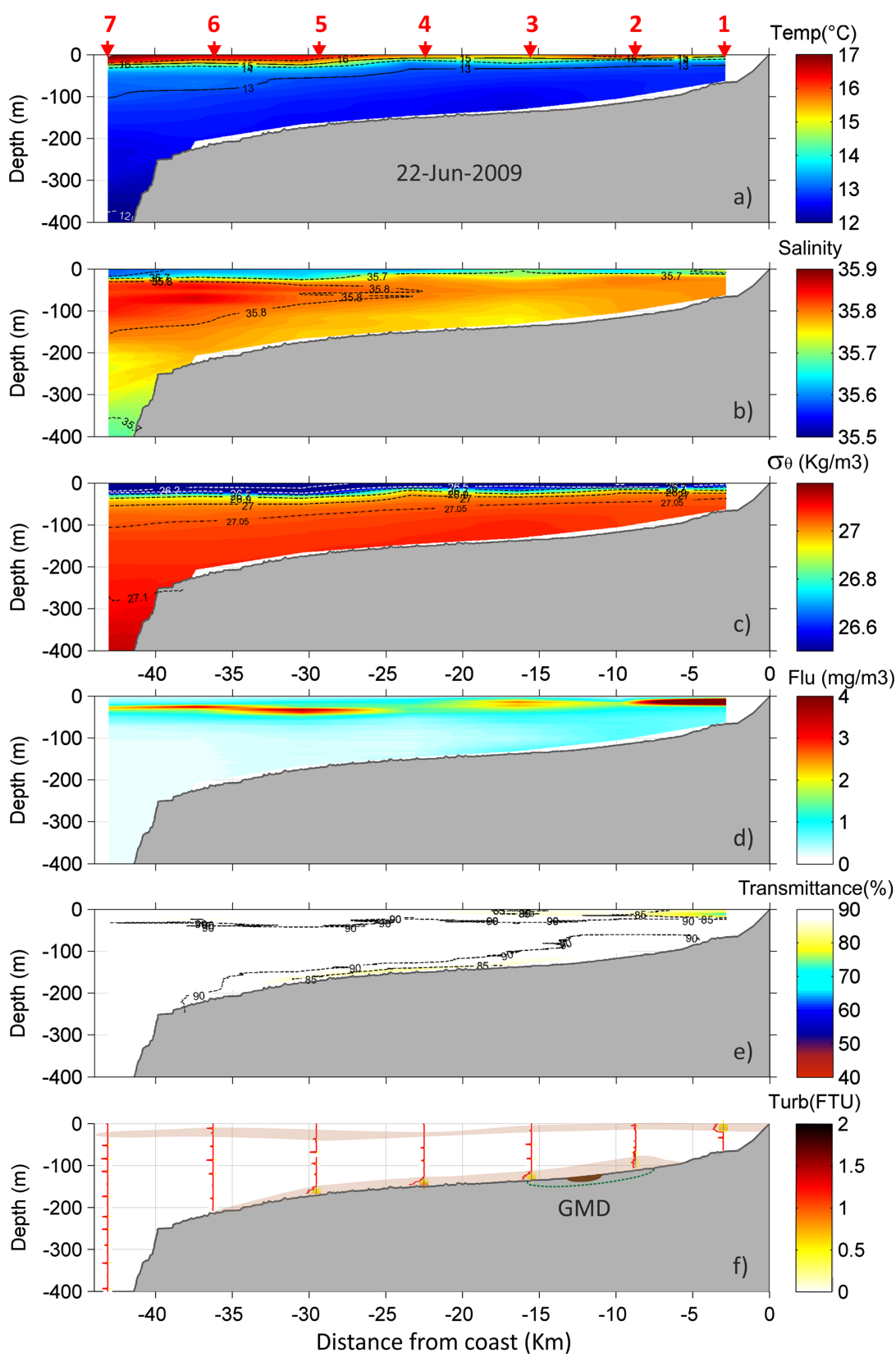

Figure 7. Hydrographic sections along $42.1^{\circ} \mathrm{N}$ during the 22 June 2009. Panels are explained in Figure 5.

$17^{\circ} \mathrm{C}$ ) and salinity ( 35.6 to 35.8 ) distributions. Near the bottom on the middle shelf, there was a temperature minimum $\left(\sim 12.5^{\circ} \mathrm{C}\right)$, concomitant with a salinity minimum of 35.75 , probably a trace from the previous upwelling event. As for the previous spring situation, a subsurface fluorescence maximum was also observed at the pycnocline depth (Figures 7c and 7d). Low levels of turbidity $(<0.6$ FTU) and high percentages of transmittance $(>82 \%)$ were detected only in a thin BNL at the middle shelf (Figures 7e and 7f). Transmittance percentage reflected an important SNL ( 75\%; Figure 7e) that was linked with biological production in the surface layers (as shown in Zúñiga et al., 2016, 2017).

\subsubsection{Downwelling and Storm Conditions: 10 November 2009}

The last selected section took place during a scenario of abrupt transition from upwelling to downwelling conditions (Figures 2 and 3). Intense northerly winds (maximum velocities of $11 \mathrm{~m} \mathrm{~s}^{-1}$ ) prevailed the week before, relaxing during the day of the cruise, and shifting to southwesterly winds just after the cruise (maximum velocities of $23 \mathrm{~m} \mathrm{~s}^{-1}$ ). This wind shift was concomitant with a circulation change from equatorward 
$\left(25 \mathrm{~cm} \mathrm{~s}^{-1}\right)$ to poleward $\left(25 \mathrm{~cm} \mathrm{~s}^{-1}\right)$ in the alongshore current component and from shoreward $\left(5 \mathrm{~cm} \mathrm{~s}^{-1}\right)$ to seaward $\left(5 \mathrm{~cm} \mathrm{~s}^{-1}\right)$ in the across-shelf bottom currents (Figure 2).

Runoff amounts were negligible in comparison with winter 2009, with values less than $100 \mathrm{~m}^{3} \mathrm{~s}^{--1}$ (Figure 2b). The wave regime was dominated by two intense storms from WNW with Hs of 5 and $5.5 \mathrm{~m}$, which occurred the week before. Another storm with $H s$ of $5.5 \mathrm{~m}$ occurred the day after the cruise with wave direction changing to west (Figures $2 \mathrm{c}$ and $2 \mathrm{~d}$ ). This postcruise storm generated a sustained peak of total combined wave-current shear stress that reached high values (up to $2.25 \mathrm{~Pa}$ ) in agreement with the values observed during the two previous storms (2.4-3.0 Pa) (Figure 3b).

The thermohaline structure responded with a slight isopycnals elevation toward the coast associated with previous upwelling conditions (Figures $8 \mathrm{a}-8 \mathrm{c}$ ). In the upper layers, a tongue of low salinity was being transported seaward by surface currents. Subsurface layers were invaded by saline waters tracing the IPC onshore advection over the continental shelf. Turbidity ( $>1$ FTU) and transmittance ( $<80 \%$ near the bottom) values showed a well-developed BNL (Figures $8 \mathrm{e}$ and $8 \mathrm{f}$ ), the most intense and largest seen in all the repeated sections off Cape Silleiro. Near the coast, the BNL covered almost the entire water column and registered the highest turbidity values (FTU $>6$ and transmittance 40\%), associated with strong wave conditions. At 9 $\mathrm{km}$ from the coast, the BNL reached $60 \mathrm{mab}$ and further offshore its height and intensity in the water column decreased, almost disappearing at the continental slope.

\section{Discussion}

\subsection{Hydrodynamics of the BBL at the Inner Galician Continental Shelf}

The deployment of an ADP on the inner Galician continental shelf over an entire annual cycle, not previously done in this region, has allowed us to study the BBL dynamics with a high temporal and vertical resolution. Our long-term time series of total shear stress showed that the highest levels occurred mainly during downwelling events in the downwelling season, when there was a coupling between wave storms and intense currents. During the entire study period, there was no clear dominance of waves or currents, and codominance situations were frequent, as indicated by Zhang et al. (2016) in the same area. In contrast, Vitorino et al. (2002) observed a clear dominance of waves for the northern Portuguese shelf, suggesting high spatial variability in terms of BBL behavior along the NW Iberian continental shelf. The most energetic wave storm conditions, promoting high shear stress levels (e.g., up to Hs $9 \mathrm{~m}$ during cyclone Klaus), came from the northwest to west, being more frequent and intense for the WNW sector (wave rose in Figure 1c). Less frequent northwesterly storms occurring during the upwelling season (March 2009) or during intense upwelling events during the downwelling season (November 2009) may also contribute to increased bottom shear stress but for shorter periods of time. On the other hand, the highest shear stress values were related to intensification of the total current and happened during the downwelling season when the ICC was predominantly northward. In this regard, it is worth noting that intensification of total current, responsible for transferring high-energy conditions to the bottom shear stress, were modulated by residual currents during all seasons, contrasting with the current regime observed at the inner part of the adjacent Ría de Vigo, where the tidal current component was the most important forcing factor (Villacieros-Robineau et al., 2013).

The high shear stress events, occurring during the downwelling season, had enough energy to exceed the threshold for the initiation of seabed sediment movement, after which the resuspension and transport of particles begin (critical shear stress $>0.1031$ Pa computed for the sediments at RAIA station; see section 2.6). This threshold of motion initiation was exceeded by the total combined wave-current shear stress values at least $67.8 \%$ of the time (considering the available time series), 51.8\% during the upwelling season, and $85.6 \%$ during the downwelling season. After the initiation of sediment motion, the total combined wavecurrent shear stress peaks were strongest during downwelling events and were correlated with both high backscatter signals in the deep-water column and high total mass fluxes registered by one sediment trap located $35 \mathrm{~m}$ above the seafloor (Figure 3). This proved that waves and currents had enough energy to resuspend surface sediments into the water column under highly hydrodynamic conditions. This explains the near absence of fine sediment on the NW Iberian inner shelf, as previously observed by other studies in which the study area was described principally by the presence of rocky outcrops and, to a lesser extent, sandy mud patches with developed bedforms such as large-wave ripples (see Figure 1b; López-Jamar et al., 1992; Dias, González, et al., 2002,Dias, Jouanneau, et al., 2002; Oberle, Storlazzi, et al., 2014,Oberle, 

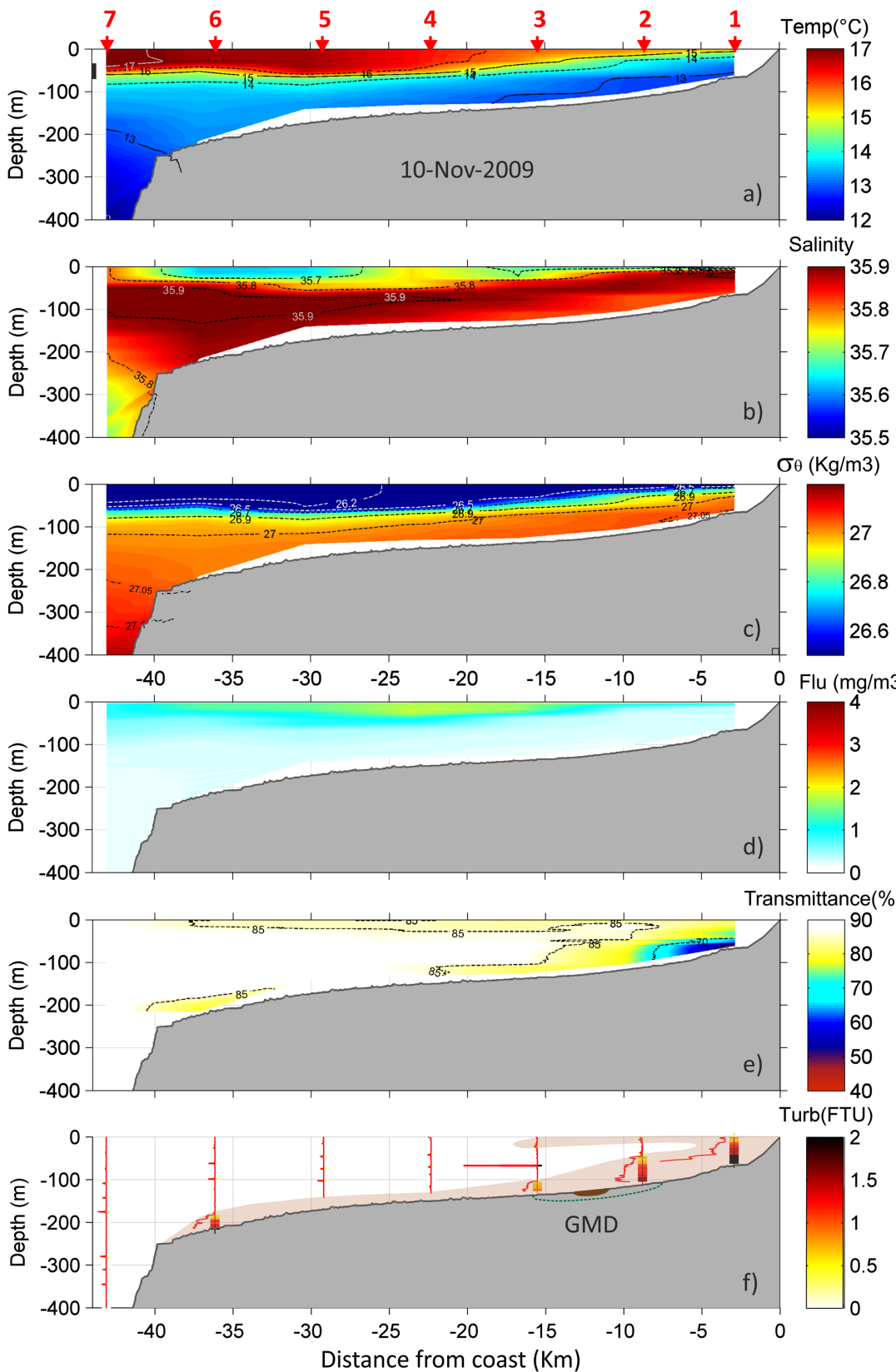

Figure 8. Hydrographic section along $42.1^{\circ} \mathrm{N}$ during the 10 November 2009. Panels are explained in Figure 5.

Hanebuth, et al., 2014). Based upon these observations, the NW Iberian inner shelf should be defined as a high resuspension inner shelf area (HRISA).

\subsection{Horizontal Export of Particulate Matter Through NLs Under Different Hydrodynamic Scenarios Off the Galician Shelf: Downwelling Versus Upwelling Seasons}

NLs are important mechanisms for the transport of particulate matter from continental shelves to the adjacent ocean (Arístegui et al., 2009). Since the observed hydrodynamics of the BBL indicated resuspension processes at the inner Galician continental shelf, the next goal of this study is to gain insights into the export (transport) of resuspended material across this margin. Based on the hydrographic sections off Cape Silleiro, we discerned two clear patterns of NLs associated with the downwelling and upwelling seasons. These seasonal patterns corresponded to the BBL hydrodynamics, to the hydrography, and to the particulate matter inputs. 
During the highly variable downwelling season, the combined effect of waves and currents achieved maximum levels of shear stress, more than sufficient to promote resuspension and erosion of surface sediments that agree with near-bottom transport events reported by Zhang et al. (2016) for this area. This is clearly shown during the autumn and winter cruises (Figures 5 and 8) when turbidity values at the inner continental shelf achieved maximum levels. In contrast, during the upwelling season, weak wave and current energy conditions at the bottom constrain the development of BNLs, and only significant SNLs were detected in the upper water column (Figures 7 and 6).

Nevertheless, our data indicated that even when combined wave-current shear stress regulates the strength of resuspension, hydrography defines the density fields. Thus, the across-shelf current circulation patterns over the inner and middle shelves determine the extension and thickness of NLs. During the downwelling season, the hydrographic structure is characterized by the presence of low salinity inner shelf waters linked to Minho and Douro river discharges (so-called WIBP) and the saltier and warmer water advected northward by the IPC (Frouin et al., 1990; Peliz, Dubert, Haidvogel, \& Le Cann, 2003,Peliz, Dubert, \& Haidvogel, 2003), confining the nearshore waters (Frouin et al., 1990; Haynes \& Barton, 1990; Castro et al., 1997; Peliz, Dubert, Haidvogel, \& Le Cann, 2003,Peliz, Dubert, \& Haidvogel, 2003; Torres \& Barton, 2006, 2007; Otero et al., 2013). This occurred on 13 January 2009 when the across-shelf extension of NLs was controlled by the position of the thermohaline front between these two water masses (Figure 5). The intersection of this front with the seabed determines the BNL extension inside the middle/inner shelf and thus can hamper the acrossshelf export of resuspended material to the adjacent ocean. Zhang et al. (2016) indicated that the position of this front determines the deposition of fine-grained sediment. At the same time, SNLs also appeared during the downwelling season due to intense river inputs (e.g., 13 January 2009; Figure 5), eroded by waves and currents and confined to the coastal zone by the hydrographic context. However, under some transitional situations from downwelling to upwelling events, the offshore extension of WIBP waters may occur (Mendes et al., 2016; Otero et al., 2013), favoring the across-shore extension of SNLs toward the adjacent ocean. In any case, the most energetic scenarios were registered during the downwelling season, when high waves and strong currents promote intense resuspension events and the ICC advects NLs northward. In contrast, during the upwelling season, the hydrographic structure responded to the across-shelf circulation pattern with an oceanward transport of surface waters and thus an offshore export of SNLs toward the adjacent ocean (5 May 2009; Figure 6).

The quantity and composition of the particulate matter inputs that contributed to the NLs were described by Zúñiga et al. $(2016,2017,2019)$ using material collected in a sediment trap deployed 35 mab on the inner shelf as well as water column biogeochemical properties. These studies showed that the highest inputs, mostly lithogenic material, occurred during the downwelling season and were associated with intense SNLs and BNLs. The origin of this material could be related with in situ resuspension, sinking particles coming from the Minho River discharges or transported from other continental shelf areas. In contrast, during the upwelling season, the SNL was mainly composed of biogenic material due to the high levels of primary production as observed by Espinoza-González et al. (2012).

In this context and based on the above discussion, we proposed two conceptual models for both downwelling and upwelling scenarios of BBL and NLs behavior and their role in the transport of particulate matter and in the surface sediment distribution. The downwelling seasonal model (Figure 9) shows three different zones: (1) the HRISA, where well-developed BNLs are generated and whose offshore extension is marked by the thermohaline front, which limits the offshore transport and favors northward advection; (2) an intermediate zone corresponding to the front location where settling conditions are more probable, as evidenced by the presence of the Galician mud depocenter (GMD); and (3) an outer shelf area influenced by the IPC and probably affected by the seabed interaction with slope currents, internal waves, or shoreward-flowing bottom currents associated with upwelling (Gross \& Williams, 1991; McCave, 1986; Oliveira et al., 2002; Thomsen et al., 2002; Zhang et al., 2019). Biogeochemical analysis of surficial sediments also points to this explanation (McCave \& Hall, 2002; Schmidt et al., 2010; Van Weering et al., 2002).

The conceptual model of the upwelling season (Figure 10) illustrates the low energy conditions at the bottom, giving rise to weaker BNLs. In contrast, the SNLs that contained mostly biogenic material were well developed in the upper water column due to high levels of primary production (Espinoza-González et al., 2012). These SNLs are transported offshore in the surface Ekman layer and, in favorable conditions, can 


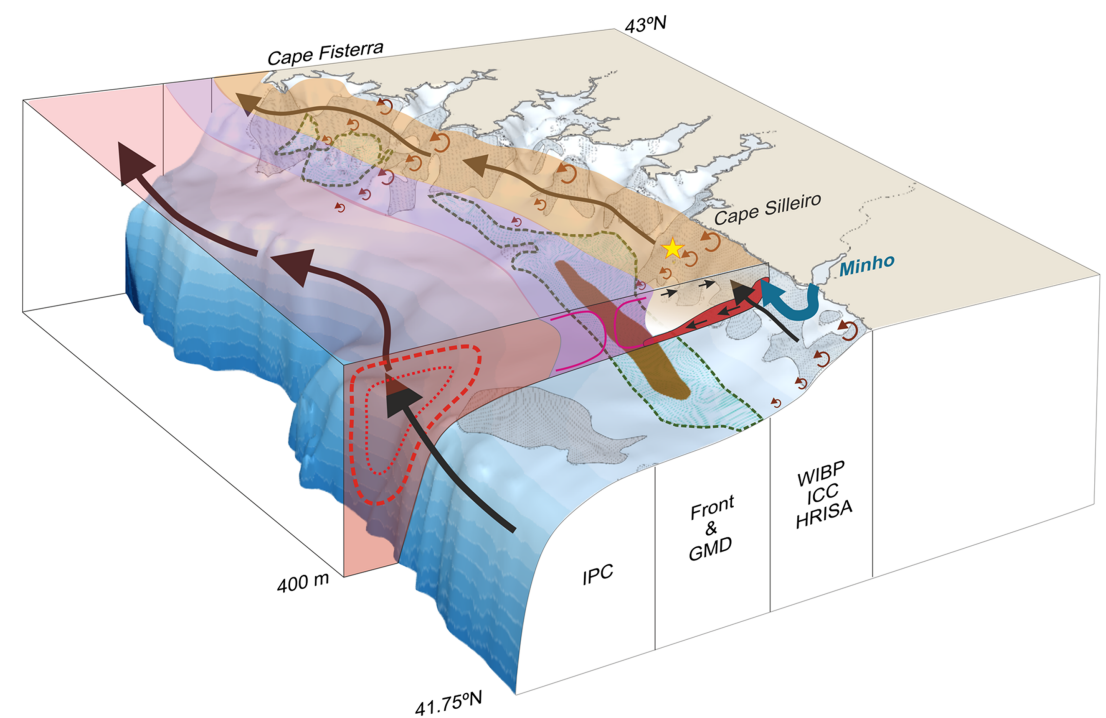

Figure 9. Conceptual transport model of particulate matter during the downwelling season. Three zones are shown: (1) the high resuspension inner shelf area (HRISA), where the Inshore Coastal Current (ICC) flows northward (thin blackbrownish arrows) and the Minho river outflows (blue arrow), (2) the intermediate zone affected by the thermohaline front and featured by the Galician mud depocenter (GMD; brown patch), and (3) the outer shelf affected by the Iberian Poleward Current (IPC; black thick arrows). In the across section, the West Iberian buoyant plume (WIBP; yellow/orange area), the BNL (red area), the seaward across-shelf bottom circulation (small black arrows), the front (magenta area), and the core of the IPC current and the area affected by the warm and saline advected waters from this current are shown. Brown loops represent resuspension processes, bottom gray areas are rocky outcrops, and yellow star is the RAIA station.

form part of upwelling filaments, similar to situations found in other coastal upwelling regions (Suess, 1980; Thunell, 1998; Zúñiga et al., 2016, 2019). If there is a relaxation of offshore Ekman transport, vertical sinking of SNL particulate matter is favored over horizontal offshore export (Zúñiga et al., 2016).

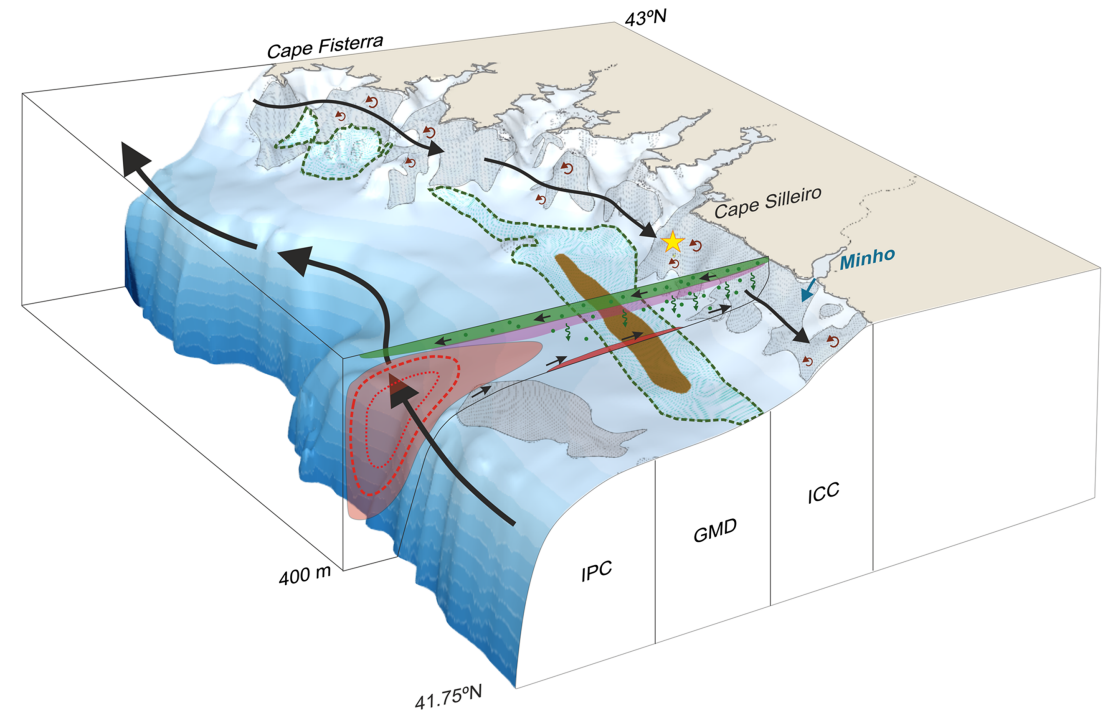

Figure 10. Conceptual transport model of particulate matter during the upwelling season. It is represented in the across section with a weak BNL (red area), the across-shelf circulation (shoreward at bottom and offshore at surface, depicted by small black arrows) indicating the favorable conditions for a filament formation, the biogenic SNL (green area), the high stratification layers (magenta area), and the weakened and deeper core of the IPC. Under low energetic conditions, pelagic vertical sinking is enhanced (small green circles). Brown loops represent resuspension processes, bottom gray areas are rocky outcrops, and yellow star is RAIA station. 


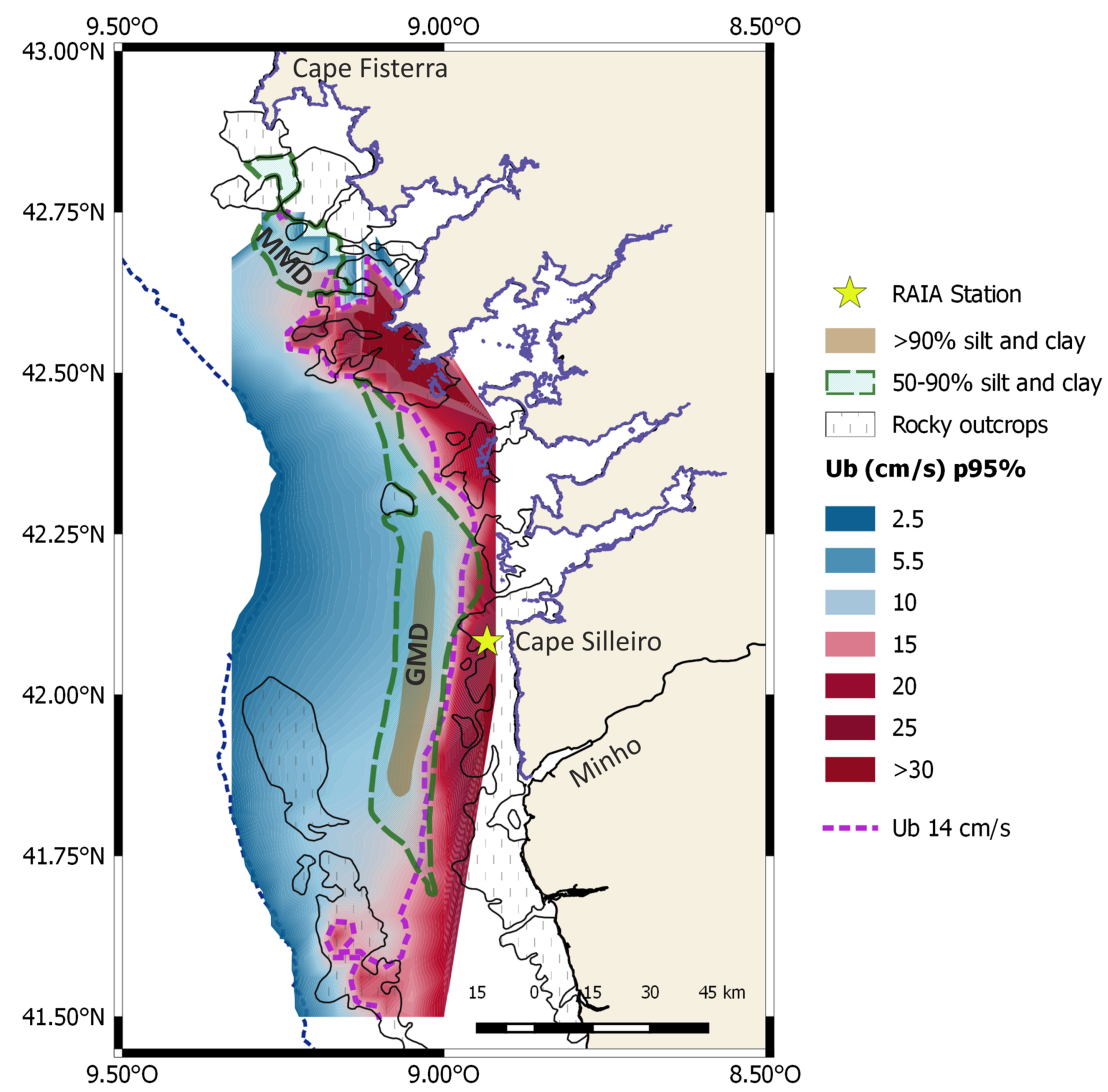

Figure 11. Spatial variability of the wave orbital velocity climate regime under stormy conditions (percentile $\left.95 \%, U_{b 95 \%}\right)$ on the Galician continental shelf. Dashed magenta line represents the $14 \mathrm{~cm} \mathrm{~s}^{-1}$ isotach. In the background the Galician and the Muros mud depocenters (GMD and MMD) are shown, the brown area depicts silt and clay concentrations $>90 \%$, and green dashed line comprises concentrations between $50 \%$ and $90 \%$. Rocky outcrops areas, the $200 \mathrm{~m}$ depth isobaths (blue dashed line), and the RAIA station (yellow star) are also shown.

\subsection{New Insights in the Dynamical Explanation of the Surface Sediment Distribution of the Galician Continental Shelf: The Role of BNL}

The proposed conceptual models for the section studied off Cape Silleiro can be extrapolated to the Galician continental shelf in order to explain the sediment distribution pattern and the position of the GMD. Our results are consistent with sedimentological processes that originate and configure a hydrodynamically controlled and detached depocenter type characterized by low sediment input and/or strong hydrodynamic conditions (Lantzsch et al., 2009). In this context, this midshelf mud belt or depocenter is well explained by the existence of a favored settling zone situated in the area of the thermohaline front during the downwelling season. At the same time, the central position of the depocenter coincides with the area where BNLs had their highest gradient of vertical height reduction (position of depocenter GMD shown in Figures 5-11) indicating possible settling processes linked to the front. In addition to this explanation, we present for first time for this region an analysis of the spatial variability of the wave orbital velocity climate regime under stormy conditions $\left(U_{b 95 \%}\right.$; Figure 11). This pattern, obtained with 59 years of hindcast wave time series, shows a clear across-shelf and alongshore gradients that partially explain the shape of the GMD.

The across-shelf variability points to a depth control of the $U_{b 95 \%}$, with a decreasing trend in $U_{b 95 \%}$ associated with isobaths deepening toward the adjacent ocean. As depth increases, the effect of waves on seafloor sediments diminishes, disappearing completely when storm waves travel on deep waters (wavelength/depth $<$ $1 / 2$ ). In fact, the zone of the strongest $U_{b 95 \%}$ decreasing gradient matches the inshore limit of the GMD (green dashed line, Figure 11). A value of $U_{b 95 \%}=0.14 \mathrm{~m} \mathrm{~s}^{-1}$ can be defined as a hydrodynamic threshold for the stability of depocenter muddy sediments and coincides with the thermohaline front inshore limit. Inward to this limit, the HRISA (Figure 9) is characterized by rocky outcrops and small proportion of 
sandy mud patches, reflecting the importance of erosion processes. Furthermore, there is a good match between the northern and southern limits of the GMD core (90\% of silt and clay) and the latitudinal $U_{b 95 \%}$ gradient (Figure 11). At the southern GMD boundary, HRISA expanded to $60 \mathrm{~km}$ from the coast over an area where the rocky outcrop distribution matches the $U_{b 95 \%}$ pattern. This gradient is clearly produced by the partial wave sheltering effect produced by Cape Fisterra that leads a reduction of wave heights in the Rías Baixas area as previously mentioned by Iglesias et al. (2009) in their study of wave energy. Complementing our analysis, a recent study by Zhang et al. (2019) proposed that the bottom shear stress generated by internal waves on the outer shelf could be strong enough to winnow unconsolidated sediments, constraining the offshore extension of the GMD.

In summary, the shape of the GMD is defined by the interaction of waves, currents, thermohaline front, and advective buoyant plumes, as happens in other mud belts (Hanebuth et al., 2015). Waves, in a long-term scale, have a primary role in the GMD shoreward boundary. However, more information about bottom current fields, eddies, or internal waves is needed to better understand the complexity of bottom dynamics on the continental shelf and their effects on the GMD shape. In future studies, it would be of considerable interest to carry out comparisons of the relative importance of these forcing conditions in this and other similar worldwide mud belt locations.

\section{Acknowledgments}

The authors wish to thank the captain, crew, and technicians of $R / V$ Mytilus as well as the Oceanography Group of the Instituto de Investigacións Mariñas (CSIC) for their collaboration during the sampling program. We are also grateful to Pablo Otero for the river discharge data and to Puertos del Estado for the meteorological and oceanographic data. VillacierosRobineau acknowledges the funding of a Juan de la Cierva-Formación fellowship (FJCI-2017-34290) from the Spanish Ministry of Science, Innovation and Universities. This work has been funded by the Spanish Ministry of Education project "CAIBEX Shelfocean exchanges in the CanariesIberian Large Marine Ecosystem" (CTM2007-66408-C02-01/MAR, CTM2007-30809-E/MAR, and CTM2008-05305-E/MAR), by the European Union FEDER project MarRISK: Adaptación costera ante el Cambio Climático: conocer los riesgos y aumentar la resiliencia

(0262_MarRISK_1_E) and by the Spanish Ministry of Science and Innovation project "i-SMALL: Importance of the "SMALL" in a changing ocean: understanding short term variability and role of small plankton (i-SMALL)" (CTM201456119-R). The upwelling index and wind time series can be obtained from the website (http://www.

indicedeafloramiento.ieo.es/). Wave time series can be freely obtained for research purpose on demand, which is found online (http://www.puertos.es). ADP current time series, sediment trap observations, and CTD surveys data are available on DigitalCSIC repository (https://doi.org/10.20350/digitalCSIC/ 8959; https://doi.org/10.20350/ digitalCSIC/8958; and https://doi.org/ 10.20350/digitalCSIC/8960, respectively).

\section{Conclusions}

Based on the longest and most detailed series of currents measurements, sediment trap observations, and hydrographic surveys carried out on the NW Iberian continental shelf to date, combined with modeled wave time series, we have advanced the knowledge of the BBL and NLs behavior of the Galician continental shelf. During more than an annual cycle, the dynamics of the BBL and of the seabed at the inner shelf depended on the variability of wave and current interaction associated with the seasonality of the upwelling influenced coastal system. Bottom shear stress achieved higher levels during the downwelling season when waves and currents were stronger favoring the seabed resuspension and the BNL development. At the same time, these downwelling conditions promoted the generation of a thermohaline front by the interaction of IPC and the WIBP that limited the offshore expansion of inner shelf NLs and thus facilitated their advection to the north within the ICC. In contrast, during the upwelling season, only thin BNLs were developed, and SNLs, principally composed by biogenic particulate material, were advected offshore in the Ekman layer often as part of the development of upwelling filaments, becoming the principal offshore export pathway in this region. The analysis of wave climate under stormy conditions, in combination with the hydrography context, is of special relevance since they showed for the first time that shoreward boundary of the GMD can be partially explained by the spatial variability of the wave orbital velocity.

\section{References}

Arístegui, J., Barton, E. D., Álvarez-Salgado, X. A., Santos, A. M. P., Figueiras, F. G., Kifani, S., et al. (2009). Sub-regional ecosystem variability in the Canary Current upwelling. Progress in Oceanography, 83, 33-48.

Bakun, A. (1973). Coastal upwelling Indices, West Coast of North America, 1946-71. US Department of Commerce, National Oceanic and Atmospheric Administration, National Marine Fisheries Service, Seattle, WA.

Barton, E. D., Torres, R., Inall, M., \& Sherwin, T. J. (2001). Vertical structure, turbulent mixing and fluxes during Lagrangian observations of an upwelling filament system off Northwest Iberia. Progress in Oceanography, 51, 249-267.

Bauer, J. E., \& Druffel, E. R. M. (1998). Ocean margins as a significant source of organic matter to the deep open ocean. Nature, $392,482-485$.

Biscaye, P. E., Flagg, C. N., \& Falkowski, P. G. (1994). The shelf edge exchange processes experiment, SEEP-II: An introduction to hypotheses, results and conclusions. Deep Sea Research Part II, 41(2-3), 231-252.

Castro, C. G., Álvarez-Salgado, X. A., Figueiras, F. G., Pérez, F. F., \& Fraga, F. (1997). Transient hydrographic and chemical conditions affecting microplankton populations in the coastal transition zone of the Iberian upwelling system (NW Spain) in September 1986. Journal of Marine Research, 55, 321-352.

Davies, A. M., Xing, J., Huthnance, J. M., Hall, P., \& Thomsen, L. (2002). Models of near-bed dynamics and sediment movement at the Iberian Margin. Progress in Oceanography, 52(2-4), 373-397.

Del Giorgio, P. A., Cole, J. J., \& Cimbleris, A. (1997). Respiration rates in bacteria exceed phytoplankton production in unproductive aquatic systems. Nature, 385(6612), 148-151.

Dias, J. M. A., González, R., García, C., \& Díaz-del-Río, V. (2002). Sediment distribution patterns on the Galicia-Minho continental shelf. Progress in Oceanography, 52(2-4), 215-231.

Dias, J. M. A., Jouanneau, J. M., Gonzalez, R., Araújo, M. F., Drago, T., Garcia, C., et al. (2002). Present day sedimentary processes on the northern Iberian shelf. Progress in Oceanography, 52(2-4), 249-259.

Espinoza-González, O., Figueiras, F. G., Crespo, B. G., Teixeira, I. G., \& Castro, C. G. (2012). Autotrophic and heterotrophic microbial plankton biomass in the NW Iberian upwelling: seasonal assessment of metabolic balance. Aquatic Microbial Ecology, 67(1), 77-89. https://doi.org/10.3354/ame01584 
Falkowski, P. G., Flagg, C. N., Rowe, G. T., Smith, S. L., Whitledge, T. E., \& Wirick, C. D. (1988). The fate of a spring phytoplankton bloom: Export or oxidation? Continental Shelf Research, 8(5-7), 457-484.

Fraga, F. (1981). Upwelling off the Galician coast, northwest of Spain. In F. Richards (Ed.), Coastal upwelling (pp. 176-182). Washington, DC: American Geophysical Union.

Frouin, R., Fiúza, A., Ambar, I., \& Boyd, T. (1990). Observations of a poleward surface current off the coasts of Portugal and Spain during winter. Journal of Geophysical Research, 95(C1), 679-691.

Godin, G. (1972). The analysis of tides (UK ISBN 0-85323-441-8.264). Liverpool: Liverpool Univ. Press.

Gross, T. F., \& Williams, A. J. III (1991). Characterization of deep-sea storms. Marine Geology, 99(3-4), 281-301.

Hanebuth, T. J. J., Lantzsch, H., \& Nizou, J. (2015). Mud depocenters on continental shelves-Appearance, initiation times, and growth dynamics. Geo-Marine Letters, 35(6), 487-503.

Haynes, R., \& Barton, E. D. (1990). A poleward flow along the Atlantic coast of the Iberian Peninsula. Journal of Geophysical Research, 95(C7), 11425-11442.

Haynes, R., Barton, E. D., \& Pilling, I. (1993). Development, persistence and variability of upwelling filaments off the Atlantic coast of the Iberian Peninsula. Journal of Geophysical Research, 98(C12), 22681-22692. https://doi.org/10.1029/93JC02016

Hedges, J. I., \& Keil, R. G. (1995). Sedimentary organic matter preservation: An assessment and speculative synthesis. Marine Chemistry, 49(2-3), 81-115.

Hidy, G. M. (1972). A view of recent air-sea interaction research. Bulletin of the American Meteorological Society, 53, $1083-1102$.

Huthnance, J., Van Haken, H., White, M., Barton, E., Le Cann, B., Coelho, E., et al. (2002). Ocean margin exchange-Water flux estimates. Journal of Marine Systems, 32, 107-137.

Hwang, J., Druffel, E. R. M., \& Eglinton, T. I. (2010). Widespread influence of resuspended sediments on oceanic particulate organic carbon: Insights from radiocarbon and aluminum contents in sinking particles. Global Biogeochemical Cycles, 24, GB4016. https://doi.org/ 10.1029/2010GB003802

Iglesias, G., López, M., Carballo, R., Castro, A., Fraguela, J. A., \& Frigaard, P. (2009). Wave energy potential in Galicia (NW Spain). Renewable Energy, 34(11), 2323-2333.

Inthorn, M., Rutgers van der Loeff, M., \& Zabel, M. A. (2006). A study of particle exchange at the sediment-water interface in the Benguela upwelling area based on ${ }^{234} \mathrm{Th} /{ }^{238} \mathrm{U}$ disequilibrium. Deep Sea Research Part I: Oceanographic Research Papers, 53(11), 1742-1761.

Jouanneau, J. M., Weber, O., Drago, T., Rodrigues, A., Oliveira, A., Dias, J. M. A., et al. (2002). Recent sedimentation and sedimentary budgets on the wester Iberian shelf. Progress in Oceanography, 52, 261-275.

Lantzsch, H., Hanebuth, T. J. J., Bender, V. B., \& Krastel, S. (2009). Sedimentary architecture of a low-accumulation shelf since the Late Pleistocene (NW Iberia). Marine Geology, 259(1-4), 47-58.

Liu, K. K., Atkinson, L., Quiñones, R., \& Talaue-McManus, L. (2010). Carbon and nutrient fluxes in continental margins. Heidelberg, Berlin, Springer-Verlag: Global Change -The IGBP Series.

López-Jamar, E., Cal, R. M., González, G., Hanson, R. B., Rey, J., Santiago, G., \& Tenore, K. R. (1992). Upwelling and outwelling effects on the benthic regime of the continental shelf off Galicia, NW Spain. Journal of Marine Research, 50, 465-488.

Masson, D. G., \& Tyler, P. A. (2011). The geology, geochemistry and biology of submarine canyons west of Portugal: Introductory remarks Deep-Sea Research Part II: Topical Studies in Oceanography, 58(23-24), 2317-2320.

McCave, I. N. (1986). Local and global aspects of the bottom nepheloid layers in the world ocean. Netherlands Journal of Sea Research, 20(2-3), 167-181

McCave, I. N., \& Hall, I. R. (2002). Turbidity of waters over the Northwest Iberian Continental Margin. Progress in Oceanography, 52, 299-313.

Mendes, R., Sousa, M. C., deCastro, M., Gómez-Gesteira, M., \& Dias, J. M. (2016). New insights into the Western Iberian Buoyant Plume: Interaction between the Douro and Minho River plumes under winter conditions. Progress in Oceanography, 141, 30-43.

Mienert, J., Abrantes, F., Auffret, G., Evans, D., Kenyon, N., Kuijpers, A., et al. (1998). European North Atlantic Margin (ENAM I): Sediment pathways, processes, and fluxes-An introduction. Marine Geology, 152(1), 3-6.

Muller-Karger, F. E., Varela, R., Thunell, R., Luerssen, R., Hu, C., \& Walsh, J. J. (2005). The importance of continental margins in the global carbon cycle. Geophysical Research Letters, 32, L01602. https://doi.org/10.1029/2004GL021346

Nittrouer, C. A. (1999). STRATAFORM: Overview of its design and synthesis of its results. Marine Geology, 154(1-4), 3-12

Oberle, F. K., Hanebuth, T. J., Baasch, B., \& Schwenk, T. (2014). Volumetric budget calculation of sediment and carbon storage and export for a late Holocene mid-shelf mudbelt system (NW Iberia). Continental Shelf Research, 76, 12-24.

Oberle, F. K., Storlazzi, C. D., \& Hanebuth, T. J. J. (2014). Wave-driven sediment mobilization on a storm-controlled continental shelf (Northwest Iberia). Journal of Marine Systems, 139, 362-372.

Oliveira, A., Vitorino, J., Rodrigues, A., Jouanneau, J. M., Dias, J. A., \& Weber, O. (2002). Nepheloid layer dynamics in the northern Portuguese shelf. Progress in Oceanography, 52, 195-213.

Otero, P., Ruiz-Villarreal, M., García-García, L., González-Nuevo, G., \& Cabanas, J. M. (2013). Coastal dynamics off Northwest Iberia during a stormy winter period. Topical Collection on Multi-scale modelling of coastal, shelf and global ocean dynamics. Ocean Dynamics, 63(1), 115-129.

Otero, P., Ruiz-Villarreal, M., \& Peliz, A. (2008). Variability of river plumes off Northwest Iberia in response to wind events. Journal of Marine Systems, 72(1), 238-255.

Otero, P., Ruiz-Villarreal, M., \& Peliz, A. (2009). River plume fronts off NW Iberia from satellite observations and model data. ICES Journal of Marine Science, 66(9), 1853-1864.

Otero, P., Ruiz-Villarreal, M., Peliz, A., \& Cabanas, J. M. (2010). Climatology and reconstruction of runoff time series in northwest Iberia: Influence in the shelf buoyancy budget off Ría de Vigo. Scientia Marina, 74(2), 247-266.

Pelegrí, J. L., Arístegui, J., Cana, L., Gonzalez-Davila, M., Hernández-Guerra, A., Hernández-Leon, S., et al. (2005). Coupling between the open ocean and the coastal upwelling region off northwest Africa: water recirculation and offshore pumping of organic matter. Journal of Marine Systems, 54(1-4), 3-37.

Peliz, Á., Dubert, J., \& Haidvogel, D. B. (2003). Subinertial response of a density-driven eastern boundary poleward current to wind forcing. Journal of Physical Oceanography, 33(8), 1633-1650.

Peliz, Á., Dubert, J., Haidvogel, D. B., \& Le Cann, B. (2003). Generation and unstable evolution of a density-driven Eastern Poleward Current: The Iberian Poleward Current. Journal of Geophysical Research, 108(8), 3268. https://doi.org/10.1029/2002JC001443

Peliz, A., Rosa, T. L., Santos, A., Migue, L. P., \& Pissarra, J. L. (2002). Fronts, jets, and counter-flows in the Western Iberian upwelling system. Journal of Marine Systems, 35(1-2), 61-77. 
Pilskaln, C. H., Paduan, J. B., Chavez, F. P., Anderson, R. Y., \& Berelson, W. (1996). Carbon export and regeneration in the coastal upwelling system of Monterey Bay, central California. Journal of Marine Research, 54, 1149-1178.

Quaresma, L. S., \& Pichon, A. (2013). Modelling the barotropic tide along the West-Iberian margin. Journal of Marine Systems, 109-110(Supplement), S3-S25.

Schmidt, F., Hinrichs, K. U., \& Elvert, M. (2010). Sources, transport and partitioning of organic matter at a highly dynamic continental margin. Marine Chemistry, 118, 37-55.

Sontek, (1997). Sontek Doppler current meters. Using signal strength data to monitor suspended sediment concentration. Sontek Application Notes.

Soulsby, R. L. (1997). Dynamics of marine sands. London: Thomas Telford.

Soulsby, R. L. (2006). Simplified calculation of wave orbital velocities. Report TR155. Release 1.0. 28pgs. HR Wallingford Ltd. http://eprints. hrwallingford.co.uk/692/1/TR155.pdf.

Soulsby, R. L., \& Smallman, J. V. (1986). A direct method of calculating bottom orbital velocity under waves. Report SR 76, HR Wallingford.

Soulsby, R.L. \& Whitehouse, R.J.S.W. (1997). Threshold of sediment motion in costal environments. Proce. Pacific Coasts and Ports'97 Conf., Christchurch,1, pp.149-54. University of Canterbury, New Zealand.

Suess, E. (1980). Particulate organic carbon flux in the oceans-Surface productivity and oxygen utilization. Nature, 288, 260-262.

Thomsen, L., Van Weering, T., \& Gust, G. (2002). Processes in the benthic boundary layer at the Iberian continental margin and their implication for carbon mineralization. Progress in Oceanography, 52, 315-329.

Thunell, R. C. (1998). Particle fluxes in a coastal upwelling zone: Sediment trap results from Santa Barbara Basin, California. Deep Sea Research Part II: Topical Studies in Oceanography, 45(8-9), 1863-1884.

Torres, R., \& Barton, E. (2006). Onset and development of the Iberian poleward flow along the Galician coast. Continental Shelf Research, 26(10), 1134-1153.

Torres, R., \& Barton, E. (2007). Onset of the Iberian upwelling along the Galician coast. Continental Shelf Research, 27(13), 1759-1778. https://doi.org/10.1016/j.csr.2007.02.005

Van Weering, T. C. E., de Stigter, H. C., Boer, W., \& de Haas, H. (2002). Recent sediment transport and accumulation on the NW Iberian margin. Progress in Oceanography, 52(2-4), 349-371.

Van Weering, T. C. E., \& McCave, I. N. (2002). Benthic processes and dynamics at the NW Iberian margin: An introduction. Progress in Oceanography, 52(2-4), 123-128. https://doi.org/10.1016/S0079-6611(02)00002-2

Villacieros-Robineau, N., Herrera, J. L., Castro, C. G., Piedracoba, S., \& Roson, G. (2013). Hydrodynamic characterization of the bottom boundary layer in a coastal upwelling system (Ría de Vigo, NW Spain). Continental Shelf Research, 68, 67-79.

Vitorino, J., Oliveira, A., Jouanneau, J. M., \& Drago, T. (2002). Winter dynamics on the northern Portuguese shelf. Part 2: Bottom boundary layers and sediment dispersal. Progress in Oceanography, 52(2-4), 155-170.

Walsh, J. J. (1991). Importance of continental margins in the marine biogeochemical cycling of carbon and nitrogen. Nature, 350(6313), 53-55.

Weaver, P. P. E., Canals, M., \& Trincardi, F. (2006). EUROSTRATAFORM Special Issue of Marine Geology. Marine Geology, 234(1-4), 1-2. Weaver, P. P. E., \& Gunn, V. (2009). HERMES hotspot ecosystem research on the margins of European seas. Oceanography, 22(1), 12-15.

Wollast, R. (1998). Evaluation and comparison of the global carbon cycle in the coastal zone and in the open ocean. In K. H. Brink \& A. R. Robinson (Eds.), The global coastal ocean (pp. 213-252). Cambridge, MA, USA: John Wiley \& Sons, Inc. ISBN 0-471-11544-4

Wollast, R., \& Chou, L. (2001). The carbon cycle at the ocean margin in the northern Gulf of Biscay. Deep Sea Res Part II: Topical Studies in Oceanography, 48(14-15), 3265-3293.

Wooster, W. S., Bakun, A., \& McLain, D. R. (1976). Seasonal upwelling cycle along the eastern boundary of the North Atlantic. Journal of Marine Research, 34(2), 131-141.

Xing, J., \& Davies, A. M. (2002). Influence of wind direction, wind waves, and density stratification upon sediment transport in shelf edge regions: The Iberian shelf. Journal of Geophysical Research, 107(C8), 3101. https://doi.org/10.1029/2001JC000961

Zhang, W., Cui, Y., Santos, A. I., \& Hanebuth, T. J. J. (2016). Storm-driven bottom sediment transport on a high-energy narrow shelf (NW Iberia) and development of mud depocenters. Journal of Geophysical Research: Oceans, 121, 5751-5772. https://doi.org/10.1002/ 2015JC011526

Zhang, W., Didenkulova, I., Kurkina, O., Cui, Y., Haberkern, J., Aepfler, R., et al. (2019). Internal solitary waves control offshore extension of mud depocenters on the NW Iberian shelf. Marine Geology, 409, 15-30. https://doi.org/10.1016/j.margeo.2018.12.008

Zúñiga, D., Kaal, J., Villacieros-Robineau, N., Froján, M., Alonso-Pérez, F., De la Granda, F., \& Castro, C. G. (2019). Tracing sinking organic matter sources in the NW Iberian upwelling system (NE Atlantic Ocean): Comparison between elemental, isotopic and molecular indicators. Journal of Analytical and Applied Pyrolysis, 139, 114-122. https://doi.org/10.1016/j.jaap.2019.01.016

Zúñiga, D., Santos, C., Froján, M., Salgueiro, E., Rufino, M. M., De la Granda, F., et al. (2017). Diatoms as a paleoproductivity proxy in the NW Iberian coastal upwelling system (NE Atlantic). Biogeosciences, 14(5), 1165-1179.

Zúñiga, D., Villacieros-Robineau, N., Salgueiro, E., Alonso-Pérez, F., Rosón, G., Abrantes, F., \& Castro, C. G. (2016). Particle fluxes in the NW Iberian coastal upwelling system: Hydrodynamical and biological control. Continental Shelf Research, 123, 89-98.

\section{References From the Supporting Information}

Amos, C. L., Bowen, A. J., Huntley, D. A., Judge, J. T., \& Li, M. Z. (1999). Ripple migration and sand transport under quasi-orthogonal combined flows on the Scotian Shelf. Journal of Coastal Research, 15(1), 1-14.

Li, M. Z., \& Amos, C. L. (1998). Predicting ripple geometry and bed roughness under combined waves and currents in a continental shelf environment. Continental Shelf Research, 18(9), 941-970. https://doi.org/10.1016/S0278-4343(98)00034-X

Nielsen, P. (1992). Coastal bottom boundary layers and sediment transport, Advanced Series on Ocean Engineering (Vol. 4). Singapore: World Scientific Publishing.

Soulsby, R. L. (1995). Bed shear-stresses due to combined waves and currents. In M. J. F. Stive, H. J. De Vriend, J. Fredsøe, L. Hamm, R. L. Soulsby, C. Teisson, \& J. C. Winterwerp (Eds.), Advances in coastal morphodynamics pp 4-20 to 4-23. Delft Hydraulics, Delft, NL, ISBN 90-9009026-6.

Van Rijn, L. C. (1989). Handbook of sediment transport by current and waves. Delft, The Netherlands: Delft Hydraulics.

Van Rijn, L. C. (1993). Principles of sediment transport in rivers, estuaries and coastal seas part 1. Amsterdam: Aqua Publications.

Yalin, M. S. (1985). On the determination of ripple geometry. Journal of Hydraulic Engineering, 3(8). 